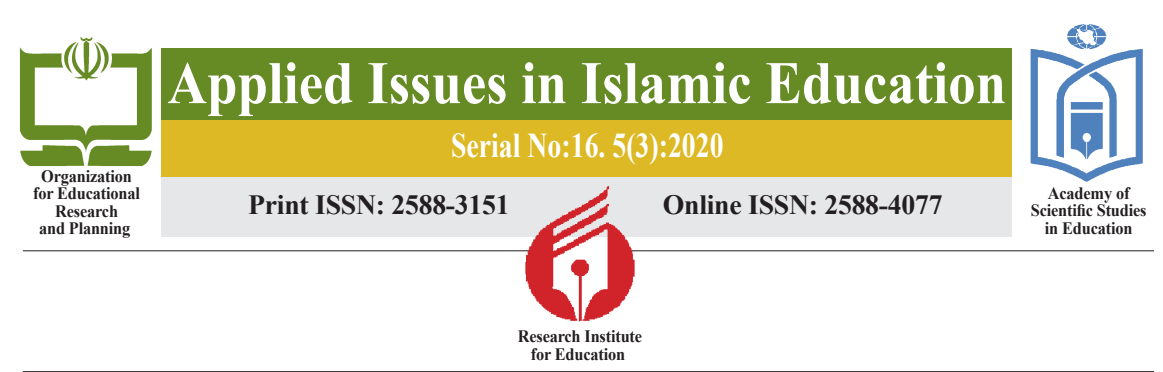

\title{
The Effectiveness of Training Spiritual Intelligence on Responsibility among the Junior High School Female Students in Qom in School Year 2019-2020
}

Fa'zeh Etemadi ${ }^{1}$, Reza Jafari Harandi ${ }^{2}$

- Objectives: This paper aimed at determining the effectiveness of training spiritual intelligence on responsibility among the junior high school female students in Qom in school year 2019-2020.

- Method: The research method was quasi-experimental with control group pretest-posttest design. The statistical population consisted of all the junior high school female students in Qom in school year 20192020. Through multi-stage random sampling method, 60 students were selected and randomly divided into experimental and control groups. For the collection of data, the Ne'mati's Adolescents Responsibility Questionnaire (2008) which is of good validity and reliability was used. The experimental group was trained in 10 sessions of 90 minutes through the spiritual intelligence training package of King (2008), which was localized and adapted to the literature of Islamic education. Data were analyzed through analysis of covariance.

- Findings: The findings showed that there is a significant difference between students' performance in responsibility and all its components except regularity in the experimental and control groups. Therefore, it can be said that training spiritual intelligence increases responsibility according to all its components except regularity, among the junior high school female students in Qom in school year 2019-2020

Conclusion: According to the findings, with a focus on training and development of teenagers' spiritual intelligence, we can improve their responsibility.

Keywords: training spiritual intelligence, responsibility, female students, junior high school, grade 8, Qom.

Citation: Etemadi,F., \& Jafari Harandi,R. (2020). The Effectiveness of Training Spiritual Intelligence on Responsibility among the Junior High School Female Students in Qom in School Year 2019-2020. Applied Issues in Islamic Education, 5(3): 7-32.

1. MA Student in Educational Psychology, Faculty of Literature and Humanities, Qom University, Qom, Iran. E-mail: mahyaparsaee73@yahoo.com. (D) 0000-0002-3371-8866

2. Corresponding Author: Associate Professor in Educational Sciences, Faculty of Literature and Humanities, Qom University, Qom, Iran.

E-mail: rjafarih@gmail.com. (D) 0000-0001-6533-6275

(C) The Authors. 


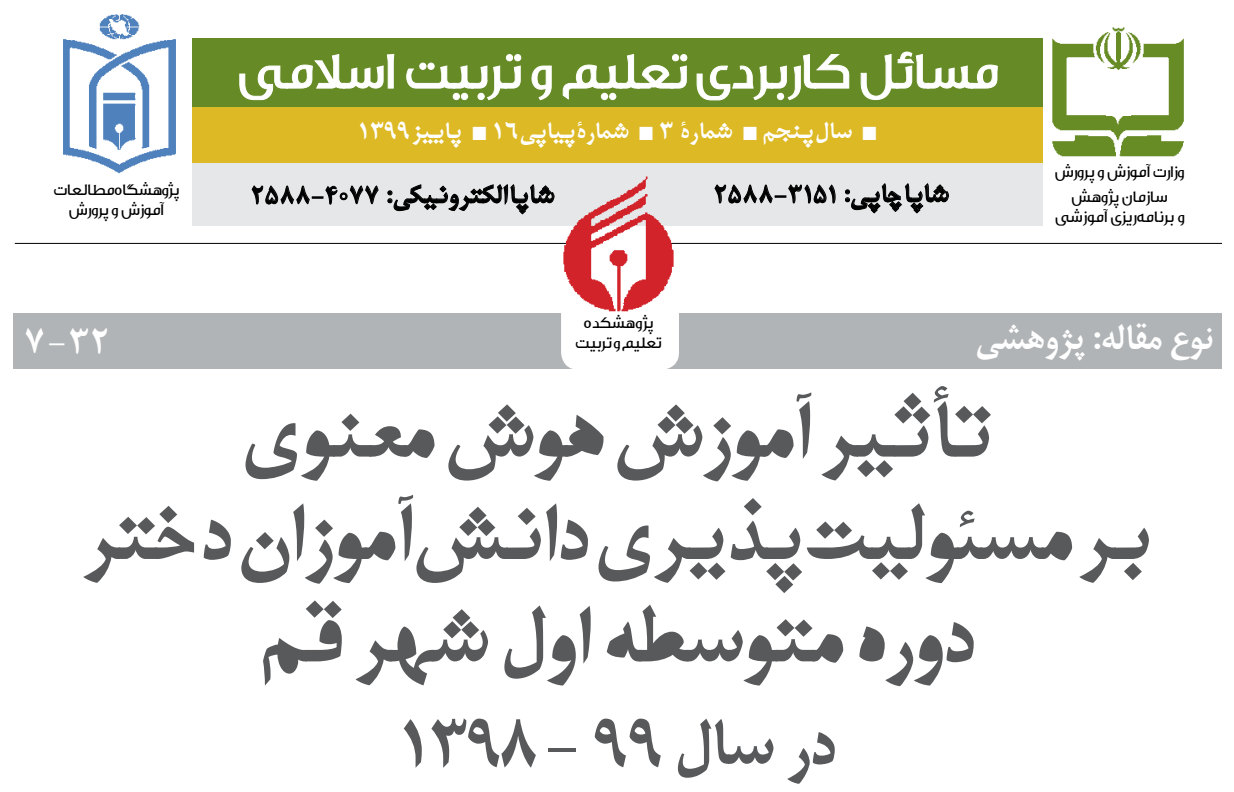

رضاجعفرى هرندى"

فائزهاعتمادى"

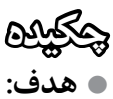

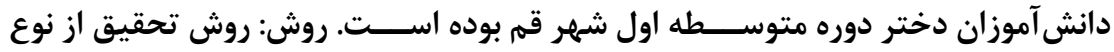

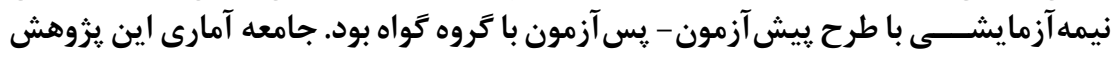
تمامى دانش آموزان دختر دوره متوسطه اول شهر قم در سر سال

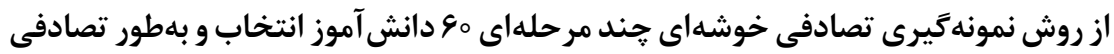

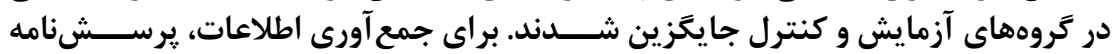

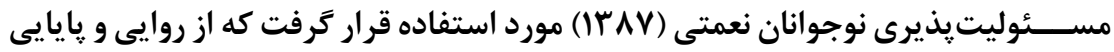

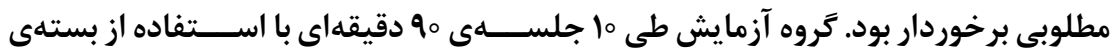

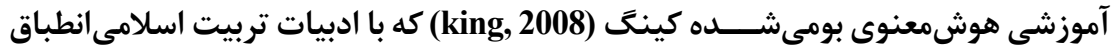

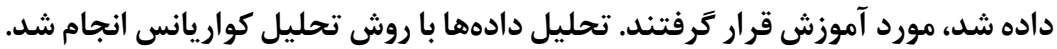

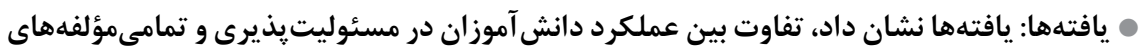

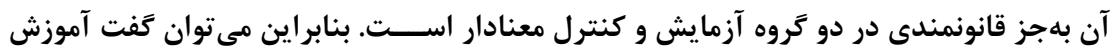

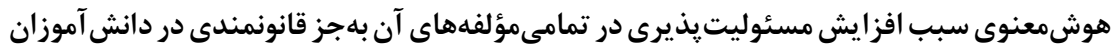

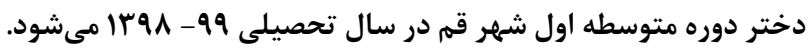

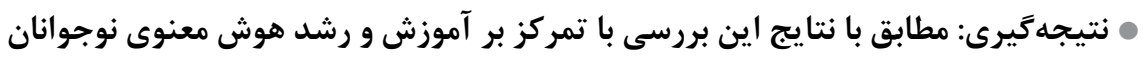

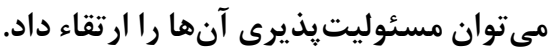

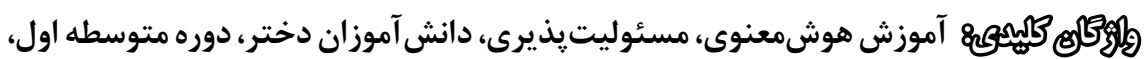
يايه هشتم، شهر قم 


\section{مقدمه}

دانش آمـــوزان بهعنــــوان ركن اصلى نظامهاى آموزشــى، در دســـيابى به اهداف و آرمانهـــاى تعليم وتربيت در تمامى جوامع نقش و جايڤاه ويـــزماى دارند و تربيت مؤثر آنها نشــاندهندهُ رشد و بارورى نظام آموزشى و تربيتى يكى كشور مى باشد (نجفزاده، Vو | ). از طرفى تربيت افراد مسئول و متعهر يكى از مهرترين و بنيادىترين هدف هر نظام تربيتى اسـت. زيرا تربيت نيروهاى مسئوليت يذير و مقيد به ارزش هاى درونىشده و با وجدان يكى از عوامل مهلم توسعه و ييشرفت هر كشور است و تربيت شخصيتهاى باثباتى كه كمتر تحت تأثير موقعيتها و شـــرايط قرار مى گيرند و با توجه به ارزشها و معيارهاى خود عمل مى كنند از اولويتها هر نظام آموزشى است. يذيرفتن مسئوليت هم نشــانه رسيدن به بلوغ است و هم وســيلهاى براى رسيدن به بلوغ. لذا مسئوليت يذيرى از مهممترين جنبههاى رشـــد نوجوانان و جوانان است و آنان در سايه يذيرش مسئوليت و مهارتهاى اجتماعى قادر به ارتباط با ديخران و ســاز كارى با اطرافيان و اجتماع خود

$$
\text { مىشوند (كلستانى، سوب ا ). }
$$

(Serto, 1989) مســـئوليتيذيرى' را يكى الزام و تعهّد درونى از سوى فرد براى انجام

مطلوب همه فعاليتهايى كه بر عهده او گذاشته شده است، تعريف مى كند و معتقد است كه مسئوليت يذيرى از درون فرد سر جشمه مى گيرد (شهيم،، سوץ ( ). (Clemes \& Bean, 1990)

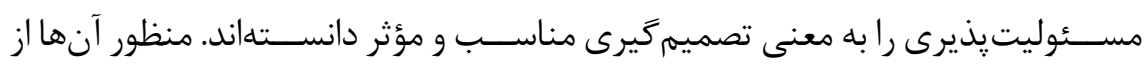

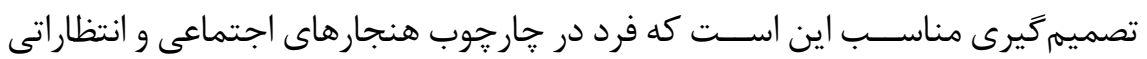
كه از او مىرود، دســت به انتخاب بزند كه ســبب ايجاد روابط انسانى مثبت، موفقيت و

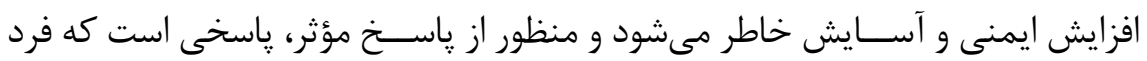

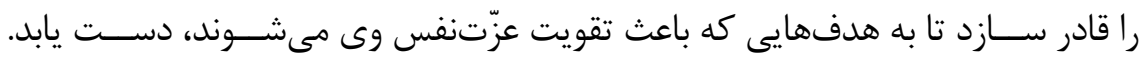
قبول مســـوليت را بزرگترين مرحله كمال انســانى دانسته است. به نظر او، افراد مسئوليتيذير، همواره اهميت كافى به انجام وظايف مىدهند و در كمك به ديخران ييشقدم هستند. بشر بدون قبول مسئوليت نمىتواند رشد كند و براى موفقيت بايد مسئوليت بِذيرد. او يايدارى در كوشش و انجام وظيفه را از صفات بارز فرد مسئوليت يذير مى داند. 
علاوه بر اهميتى كه ادبيات غرب براى مســئوليتيذيرى قائل است، در اسلام نيز همواره از مسئوليتيذيرى بهعنوان مهمترين هدف تربيتى و يراهميت ترين مؤلفهاى برى

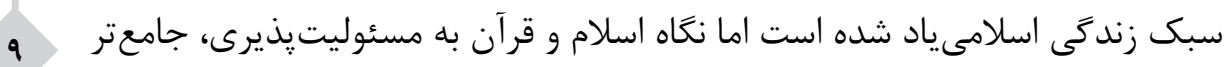

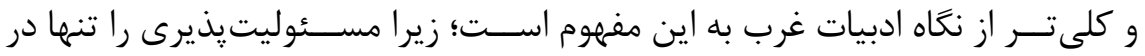

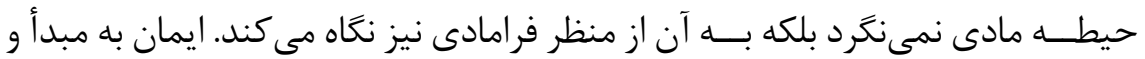

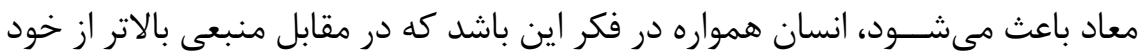

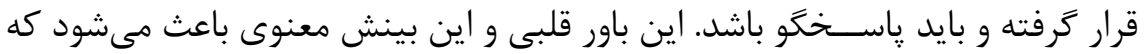
انســان ديندار باعمق وجود خود مســـوليت را درك و قبول نمايد (داداشـى كلايى، ه9؟1). از نظر اســلام، انســان موجودى است كه نســبت به همنوعان خود احساس

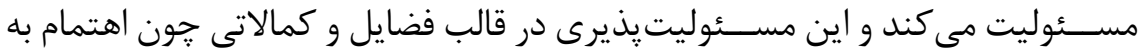
امور ديكران، انساندوســتى، سودرســانى به همنوعان، نظم در كار و زندكى فردى و اجتماعى، مردم رايى و تعاون و همكارى متبلور مىشــود. به بركت حسّ مسئوليت و تكليف اســت كه انســان مىتواند از جنكال زمين رها شود و بهسوى عالم بالا به يرواز درآيد. انســان امانتدار بزرى خداست و مســئوليت او در بيشگاه خدا، خود و جامعه

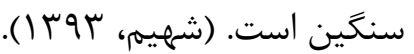
در قرآن مجيد آيات فراوانى وجود دارد كه اهميت مســـئوليتيذيرى را براى انسان

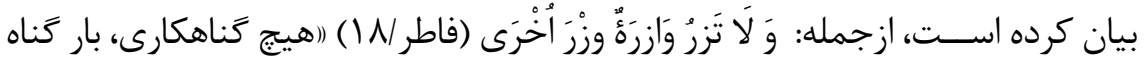

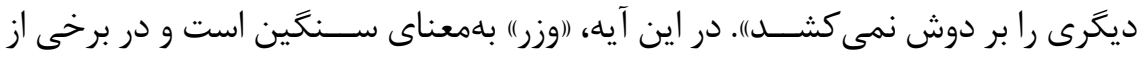

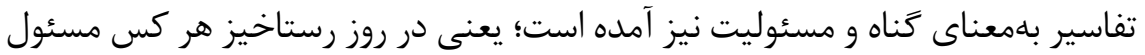

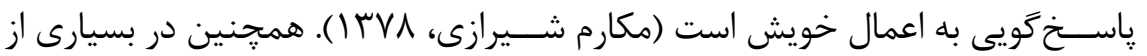
تفاســير آمده است كه منظور از امانت الهى (احزاب، VY) همان تعهّد و قبول مسئوليت است و علت اين كه اين امانت عظيم، به انسان سيرده شده است، اين بود كه او اين قابليت

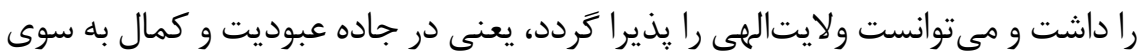

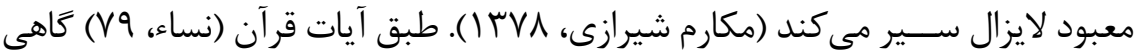

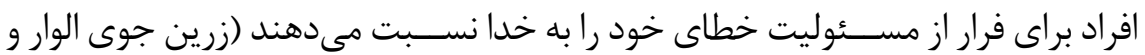

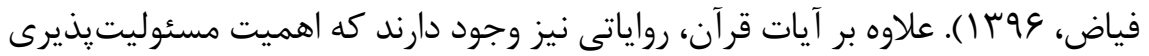

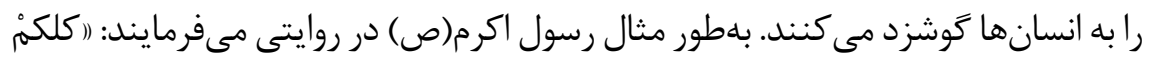




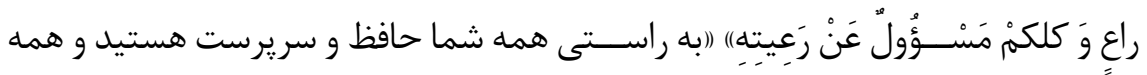
شما جوابكً و مسئول مردم زيردست خود هستيد) (حسينى، ايزدى، وكيلى و انصاريان،

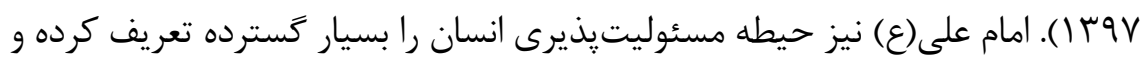
به كار زَاران خود در خصوص مسئوليت يذير بودن نسبت به كليه كارها و اقدامات جنين

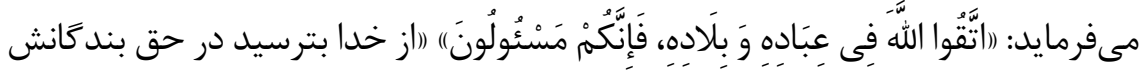
و شهرهايش، زيرا شما مسئوليد) (نهج البلاغه، خطبه (1)V). در ســــى زندگى اسلامى، مسئوليتهاى مشخص انسان به تفصيل بيان شده است.

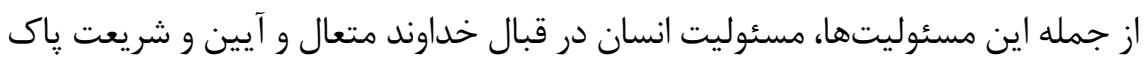
الهى و مسئوليت انسان در قبال خود، ديخران و جمان هستى مىباشد كه در صورت توجه، يذيرش و شكوفاسازى تمام اين ابعاد، زندگى آدمىنظامى مطلوب به خود مى گيرد و انسان

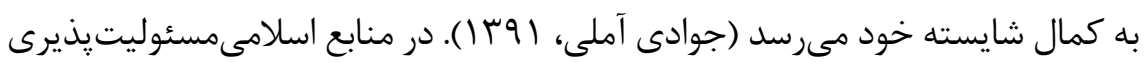

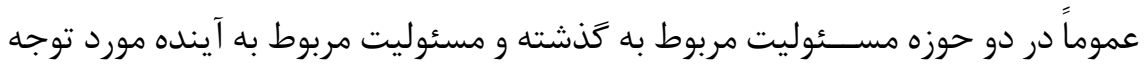
قرار مى گيرد. مطهرى نيز مسئوليت ڤذيرى را شامل سه عنصر مى داند، يك، بشردوستى،

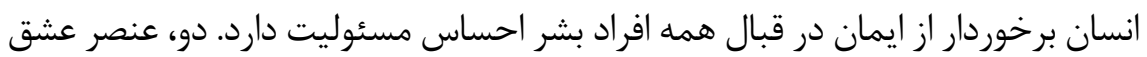
كه مقدمه همزيستى ير از لطف در روح انسان است و مقدمه يخانگى و وصول به حقيقتى عالىتر از افق انسان است. سومين عنصر در مسئوليت قذيرى آزادى است. انسان بايد آزاد باشد تا به كمالات خود برسد، جون آزادى يعنى اختيار انسان در ميان موجودات، انسان تنها موجودى اســت كه خود بايد راه خود را انتخاب كند حتى به تعبيرى خودش بايد خودش را انتخاب كند، يس انســان آزاد و مختار است و در مقابل اين آزادى مسئوليت دارد و بايد بين مسئوليت و اختيار توازنى باشد و الا هر دو بىمعنى خواهند بود (مظفرى

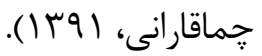
تاكنون يزوهشهاى زيادى نيز انجام شــده اســت كه اهميت مسئوليتيذيرى را به خوبى نمايان مىسازند. بهطور مثال در يزوهشى كه توسط (Lovin \& Eskovartez, 2001) انجام شــد، نتايج نشان داد كه عدم يرورش حس مسئوليت ٍذيرى در نوجوانان، سلامت هويت آنها را به خطر مى اندازد؛ يعنى يا رشــد هويــت آنها را متوقف مى كند و باعث مىشود فرد ديرتر به بلوغ فكرى برسد و يا منجر به شناخت سطحى او از زندگى مى

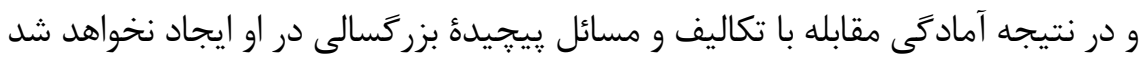




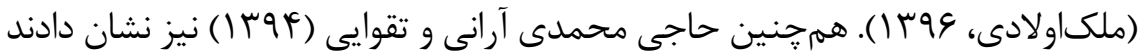
كه مســـوليت يذيرى دانشآموزان بهطور معنادارى ييشرفت تحصيلى آنها را ييشبينى

خواهد كرد. امّا متأسفانه علىرغم اهميت اين موضوع، با نخاهى كذرا به مسائل انضباطى نوجوانان مى توان دريافت كه هنوز تلاش كافى در جهت شـــاخت و آموزش اين مهارت در بين نوجوانان انجام نشــده است. بهطور مثال سفيرى و جشمه (سوسا () نشان دادند كه ميزان مسئوليت ڤذيرى در نوجوانان بسيار يايين بوده بهطورى كه حدود ال درصد از ياسخ گويان از نظر مسئوليتيذيرى در حد متوسط و يايين قرار دارند. همجنين خرمدل (I INV) برخوردارند، با اين توضيح كه در نمونههاى اين يزوهش تنها سا درصد از ياسخ گويان در متغير ميزان مســـوليتيذيرى نمره قابل قبولى بهدست آوردهاند و اين امر نخران كننده اســت زيرا نوجوانان ما آيندهسازان جامعه هستند، اخر به يرورش حسّ مسئوليتيذيرى در آنان توجه نشود با افراد بىمســــوليتى برخورد خواهيم كرد كه براى انجام وظايفشان به ديخران متكى هستند. از آنجايى كه مسئوليت يذيرى بهعنوان يك مهارت، آموختنى و قابل اكتساب است، مىبايســت به دنبال راههايى باشــيم كه منجر به رشد و توسعه اين مهارت در نوجوانان خواهد شد. با مرورى بر يِيشينه نظرى و تجربى متغير مسئوليتيذيرى، مىتوان دريافت كه هوشمعنوى' ازجمله عوامل بسيار مهمى است كه ميىتواند تأثير قابل توجهى بر اين متغير داشــــه و سبب رشد و توســـهُ اين مهارت در نوجوانان شود. در اين راستا گويتا

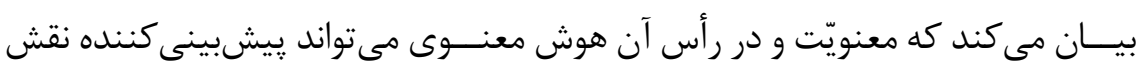
مسئولانه افراد در حل مشكلات و مسائل ير تنش روزمره در موقعيتهاى مختلف ازجمله موقعيتهاى آموزشى باشد (Gupta, 2012). از آنجايى كه افرادى كه هوش معنوى بالايى دارند احســاس تعهد و مسئوليت بيشترى نســبت به باورها و ارزشهاى خود خواهند داشــت، اين احساس تعهد و مســـئوليت ڤذيرى به ديخر عرصههاى زندگى آنها نيز راه خواهد يافت و بهتدريج نسبت به تمامى تكاليف خود در زندگى احساس مسئوليت خواهند كرد و لذا مىتوان گفت هوش معنوى و احساس تعهد نسبت به باورهاى معنوى، ويزگى مسئوليت يذيرى را در اين افراد ايجاد كرده است. 
مفهوم هوش معنوى براى اولين بار در ادبيات علمىروانشناسى توسط (Stivenz, 1996) و بعد توســـ (amons, 1999) مطرح شـــد و بهعنـــوان يكى از جديدترين ســـازهـا در روانشناسى و علمم مديريّت در مركز توجّهات قرار گرفت (تيزروطولى و نريمانى، Vوس I). هوش معنوى بر طبق تعريف زوهر و مارشال توسعه اشتياق و ظرفيت ما براى درك معانى، بصيرت و ارزش است كه باعث تسهيل تبادل كفتخو بين منطق و احساسات، بين جسم و ذهن مىشود و ما را قادر مى سازد كه تبادل درون فردى و ميان فردىمان را يكيار جه سازيم. (Zohar \& Marshal, 2000). جاين و يورهيت هوش معنوى را توانايى تجربه شدهاى مى دانند كه به افراد امكان دســتيابى به دانش و فهمم بيشــتر را مى دهد و زمينه را براى رســيدن به كمال و ترقى در زندگى فراهم مى ســــازد. هوش معنوى بهعنوان روشهاى

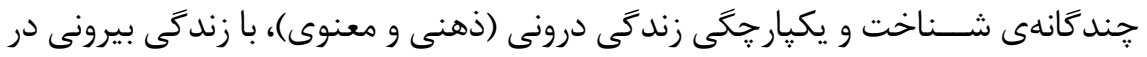
جهان ناميده مىشود. بنابراين مىتوان كفت كه هوشمعنوى تمام آن جيزهايى است كه به آن معتقد هستيم و نقش باورها و هنجارها، عقايد و ارزشها را در فعاليتهايى كه بر عهده مى گيريم، نشان مىدهد (Jain \& Purohit, 2006). هوش معنوى در بر گيرنده نوعى ســاز گارى و رفتار حل مسئله است، كه بالاترين ســـوح رشد را در حيطههاى مختلف شـــاختى، اخلاقى، هيجانى و بين فردى شامل مىشود، و فرد را در جهت هماهنكى با يديدههاى اطراف و دســتيابى به يكيارجگىى درونى و بيرونى يارى مىنمايد. اين هوش به فرد ديدى كلى در مورد زندگى و همةٔ تجارب و رويدادها مى دهد و او را قادر مىسازد به جهار جوب جندى و تفسـير مجدد تجارب خود يرداخته، شناخت و معرفت خويش را عمق بخشـــد (صبا و اصل فتاحى، وهץ (). افرادى كه هوشمعنوى بالايى دارند، ظرفيت تعالى داشته و تمايل بالايى نسبت به هوشيارى دارند. آنان اين ظرفيت را دارند كه بخشى از فعاليتهاى روزانهى خود را به اعمال روحانى و معنوى اختصاص دهند و فضايلى مانند بخشش، سياسگًارى، فروتنى، دلسوزى و خرد را از خود نشان ميدهند. هوشمعنوى به

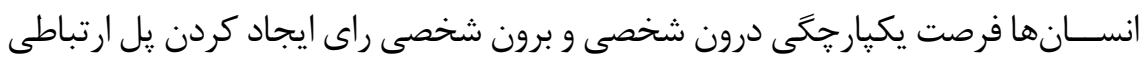

بين خودشان و ديخران را مىدهد (Sisk, 2008). هرجند مفهوم هوش معنوى براى اولين بار در غرب مطرح شـــده اســت، اما اين به اين معنا نيســت كه در اسـلام به اين مفهوم توجه نشده يا مغفول مانده است. در اسلام نيز هوشمعنوى مورد تاكيد فراوانى قرار گرفته است. با اندكى بررسى در متون اسلامى، 
همجون قرآن و نهج البلاغه، مطالب مربوط به هوش معنوى و مترادفها و يا معادل هاى آن، به وفور يافت مىشـــود. بهطور مثال در قرآن كريمم از افرادى كه هوشمعنوى بالايى دارند، بهعنوان اولوالالباب ياد شده است. سهرابى (وجس ا ) ضمن بررسى آيات قرآن كريم

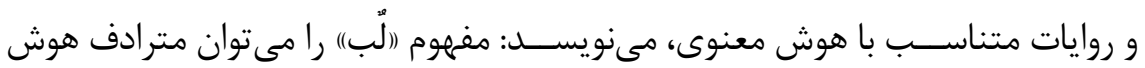

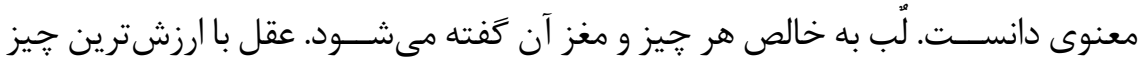
انسان است و ساير اعضاى انسان به مثابه يوست و براى محافظت از اين شىء نفيس است و لٌّ عقلى خالص است. به همين دليل قرآن كريم توجه ييدا كردن و متذكر شدن نسبت بـــهـ برخى امور دقيق را كه انجام آنها از عهده هر عقلى بر نمى آيد، به اولوالالباب، يعنى هـي صاحبان عقل خالص احاله كرده اسـت (يدالله يور و فاضلى كبريا، سوس (). امام على(ع) نيز در نهج البلاغه هوش معنوى را شــامل: (اخودآكاهى، خودانگيختخى، ارزش مدارى و

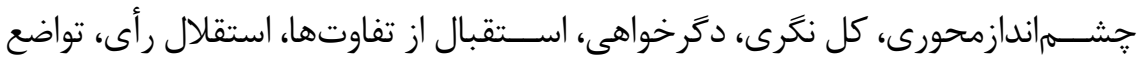
و فروتنى، تمايل به طرح جراهاى بنيادى، توانايى تغيير جارجوبههاى ذهنى، اســتفاده

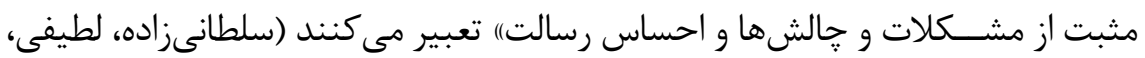

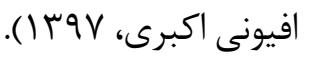

مصاديق هوش معنوى در آموزههاى اســلام بيشتر با مفاهيم و مصاديقى همخوانى دارد كـــه بيانكر عنصـــر (توانايى)" و در عين حال عنصر ((ارزش و معنويت)) اســت كه به عقل توحيد بخشـــيده اســت و در قالب هوش معنوى تجلى ييدا كرده است. اين مفهوم در جســتجوى معناى زندگىى، استفاده از نمادها و سمبل هاى دينى، تبديل مشكلات به

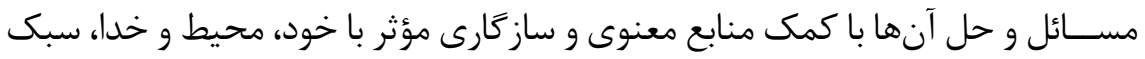

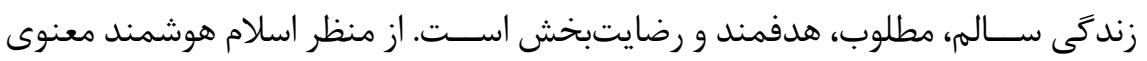
همان انسان مؤمنى است كه مهارت و قدرت تعالىبخشى خود و ديخران را به ساحت برتر

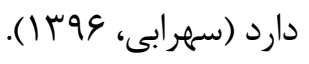

در قرآن مجيد انسانها به يرورش صفات و ويزگگىهايى از قبيل: بخشش، شكيبايى،

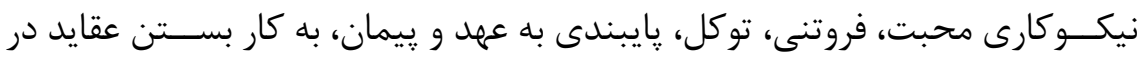

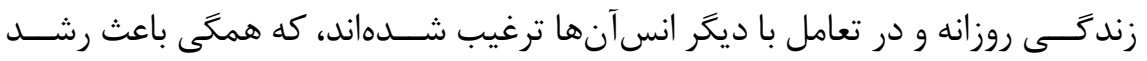

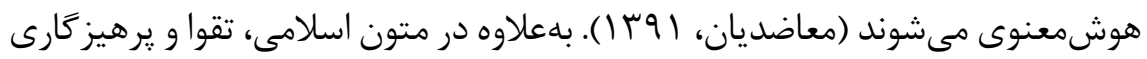
بـــه همراه تمرينات روزمرّه از قبيل تدبر در خلقــت، تدبّر در آفاق و انفس، روزهدارى، 
عبــادت، خواندن قرآن و تدبّر صادقانه در آيات بهعنـــوان عوامل مؤثر بر هوش معنوى قلمداد شده است (حميد و زمستانى، بوس ()). تاكنون تحقيقاتى در ايران و كشــورهاى خارجى در زمينـــهـ مسئوليتيذيرى انجام شده اســت كه ارتباط اين متغير با عوامل ديخرى همجون هوشمعنوى را مورد بررسى قرار دادهاند. در ادامه به برخى از تحقيقات انجام شــده دراين زمينه مى يردازيم. رستخار

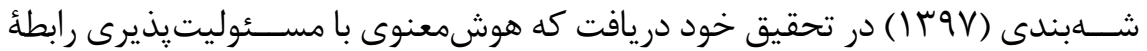

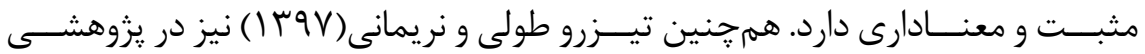
نشــان دادند كه آموزش هوش معنوى بر مســئوليتيذيرى و قانونمندى دانشآموزان

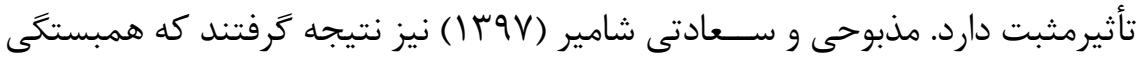
بين هوشمعنوى با مســـئوليتيذيرى معنـــادار بوده و بين نمره كلــى هوشمعنـوى با

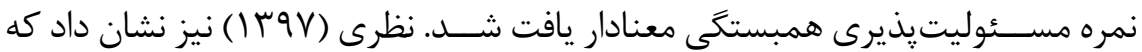
ميان زيـــر مقياسهاى هوش معنوى و مســــوليت پذيرى رابطهُ معنـــادارى وجود دارد.

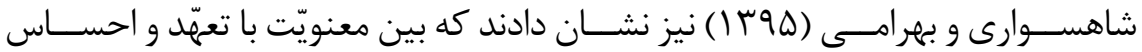
مســــوليت در دانشآموزان رابطة مثبت و معنادارى وجود دارد. عزيزى نزاد، ســـيدى

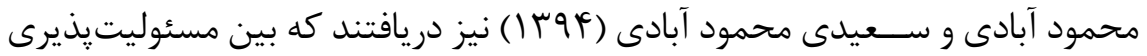

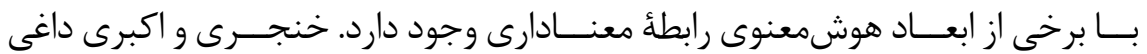

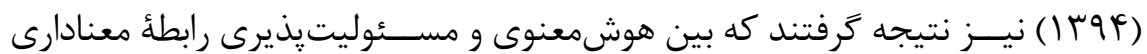
وجـــود دارد. نعمتى و كيانلو شهرســتانكى (سوس ( ) نيز بيــان كردند كه بين نمره كلى مســـئوليت يذيرى و هوش معنوى نيز رابطةُ مثبت و معنادارى وجود دارد. رســولى نزاد،

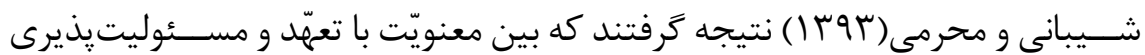
در دانشــجويان رابطهُ مثبت و معنى دارى وجود دارد و افرادى كه داراى معنويّت بالاترى هســـتند از ميزان تعمّدد و احســاس مسئوليت بيشترى نسبت به ســايرين برخوردارند. نيز نتيجه كرفتند كه (Javadi Nejad, Heidari, Naderi, Bakhtiyar Pour \& Haffezi, 2019) آموزش هوش معنوى مسئوليتيذيرى را در دانشآموزان افزايش مىدهد. (Kaur, 2018) نيز نشــان داد كه بين مسئوليت يذيرى اجتماعى با معنويّت و هوش معنوى كلى ارتباط مثبــت و معنـــادارى وجـــود دارد. (Joseph \& Lakshmi, 2012) نيز دريافتند كه رشــد هوشمعنوى فرد به تنهايى مىتواند مهارتهايى مانند مسئوليت ٍذيرى توسعه بخشد. 


\section{V-rr}

باوجود اينكه در اين تحقيقات تا حدودى به موضوع يثرهش يرداخته شده است اما از آنجا كه مفهوم مسئوليت يذيرى هسته مركزى اهداف غايى يك انسان بوده و اهميت قابل

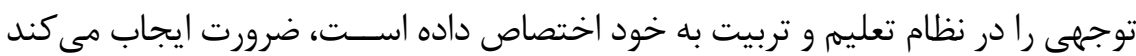
كه تحقيقات بيشــترى در اين زمينه صورت گيرد. همجنـين با مرور ادبيات يثوهشـىى انجام شــده درمورد مسئوليتيذيرى، مى توان مشاهده كرد تحقيقاتى كه در گذشته در

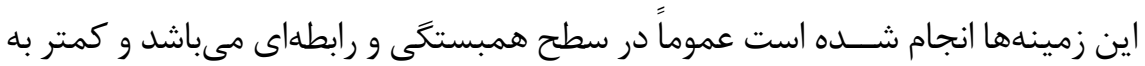
بررســى تأثير مستقيمم آموزش هوشمعنوى بر مسئوليت يذيرى نوجوانان در قالب طرح نيمها آزمايشــى برداختهاند، ازين رو اين يزوهش درصدد اســت تا با روش نيمهآزمايشى

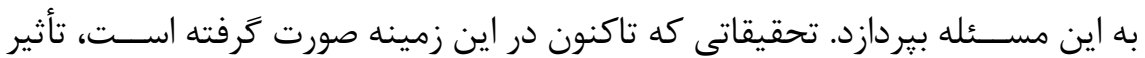
عوامل مختلفى را بر روى اين متغير مورد بررســى قــرار دادهاند، اما در اين يثرهش به

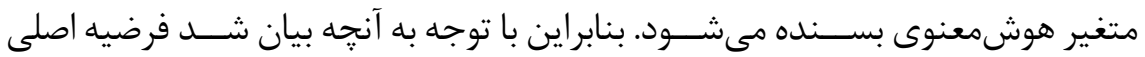
عبارتســت از اينكه آموزش هوش معنوى سبب افزايش مسئوليتيذيرى و مؤلفههاى آن در دانشآموزان دوره متوسطه اول شهر قم در سال 99-91 9 ا مىشود.

\section{روش تحقيق}

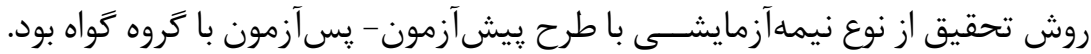
جامعه آمارى اين يزوهش كليئ دانشآموزان دختر دوره متوســطه اول شهر قم در سال

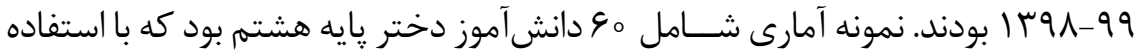

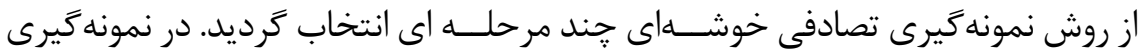
تصادفى ابتدا از بين \& ناحيةٔ استان قم، ناحيه ب و از بين مدارس اين ناحيه يك مدرسه بهصورت تصادفى انتخاب شد. از اين مدرسه r كلاس يايه هشتم انتخاب گرديد. سيس يكى از كلاسها بهعنوان گروه گَواه و ديخرى بهعنوان گروه آزمايش انتخاب شــد. حجم نمونه براى هر گروه، سـى نفر در نظر گرفته شد. از مهرمترين متغيرهاى مزاحم در اين يزوهش شركت در ديخر مراسمات مذهبى مانند عزادارىهاى دينى در ماه محرم و صفر، مراسمات مذهبى ماه رمضان و غيره بود كه براى كنترل اين متغير زمان اجراى اين برنامه در زمان بدون مناسبت مذهبى صورت گرفت. بهطور كلى در اين مطالعه، ملاكهاى ورود

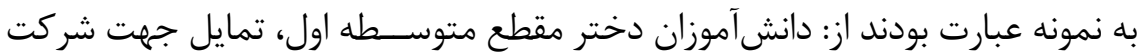


در يزوهش و عدم شركت در جلسات آموزشى و مشاورهاى بهصورت همزمان. ملاكهاى

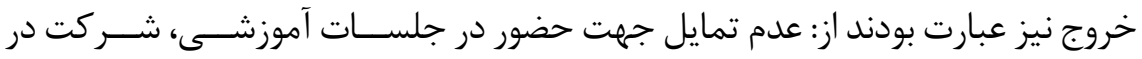
جلسات آموزشى و مشاورهاى ديخر بهصورت همزمان و غيبت از جلسات آموزشى به مدت r جلسه. لازم به ذكر است كه در اين ثيزوهش افت آزمودنى وجود نداشت.

جدول ا. بازنمايى از طرح تحقيق

\begin{tabular}{|c|c|c|c|}
\hline بسى آزمون & متغير مستقل & بيش آزمون & كروه. \\
\hline مسئوليت پِذيرى نوجوانان & جلسات آموزش در & مسئوليت يُشيرى نوجوانان & آزمايش \\
\hline مسئوليتيذيرى نوجشوانان & در جلسات شركت آموزش & 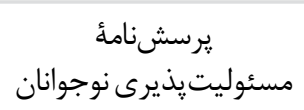 & كنترل \\
\hline
\end{tabular}

\section{بسته آموزشى و روش اجرا}

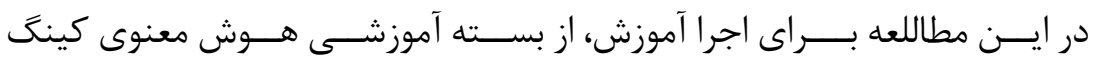
(king, 2008)

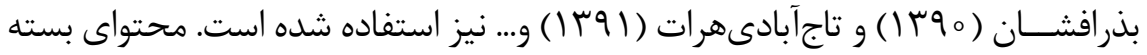
آموزشــى قبل از شـــروع آموزش در اختيار متخصصان روانشناســى اسلامى و اساتيد مربوطه قرار گرفت و مثال ها و توضيحاتى در قالب آموزههاى اســلامىبـه آن اضافه شــد كه اعتبار اين محتواى افزوده شده مورد تأئيد متخصصان در اين حوزه بود. پِ آ از اينكه

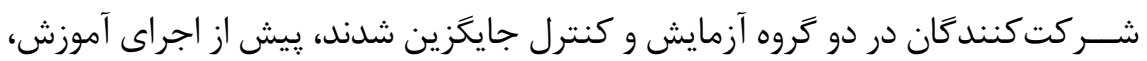

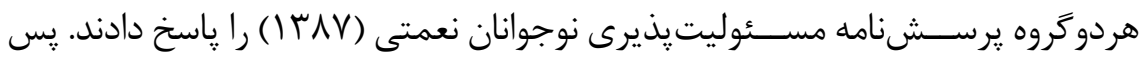

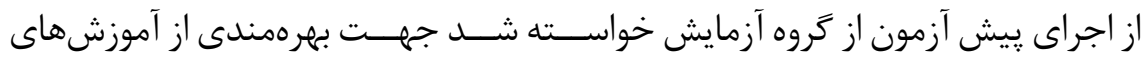

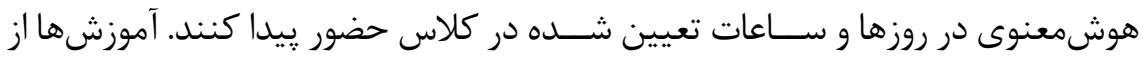
تاريخ ا آذر ماه ســال تحصيلى 99-91 آغـــاز زرديد. با توجه به محتواى مورد آموزش، زمان جلســات ه9 دقيقه بود كه به مدت r ماه و طلى ه آ جلســــه ادامه يافت. روشهاى آموزشى شامل ســخنرانى آموزشى، بحث كلاســى، بارش فكرى و روش سقراطى بود. اين آموزشها توســـ يزوهشـــر و با همكارى مشاور مدرسه كه خود نيز از متخصصان روانشناسى اسلامىبودند، انجام شد. از آمودنى ها خواسته شد تا همگى در بحث كلاسى ميى 


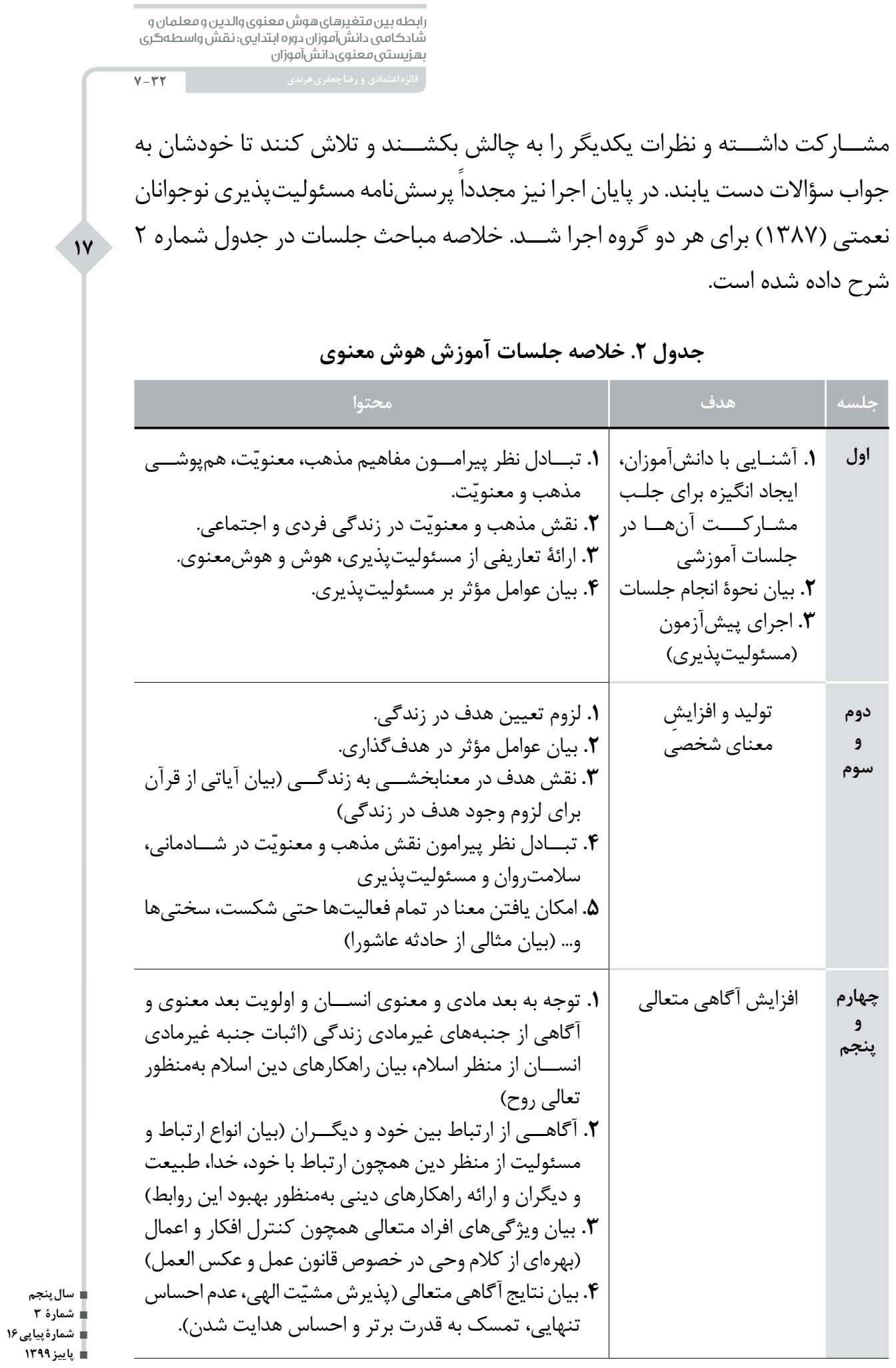




\begin{tabular}{|c|c|c|}
\hline محتوا & هدف & جلسه \\
\hline 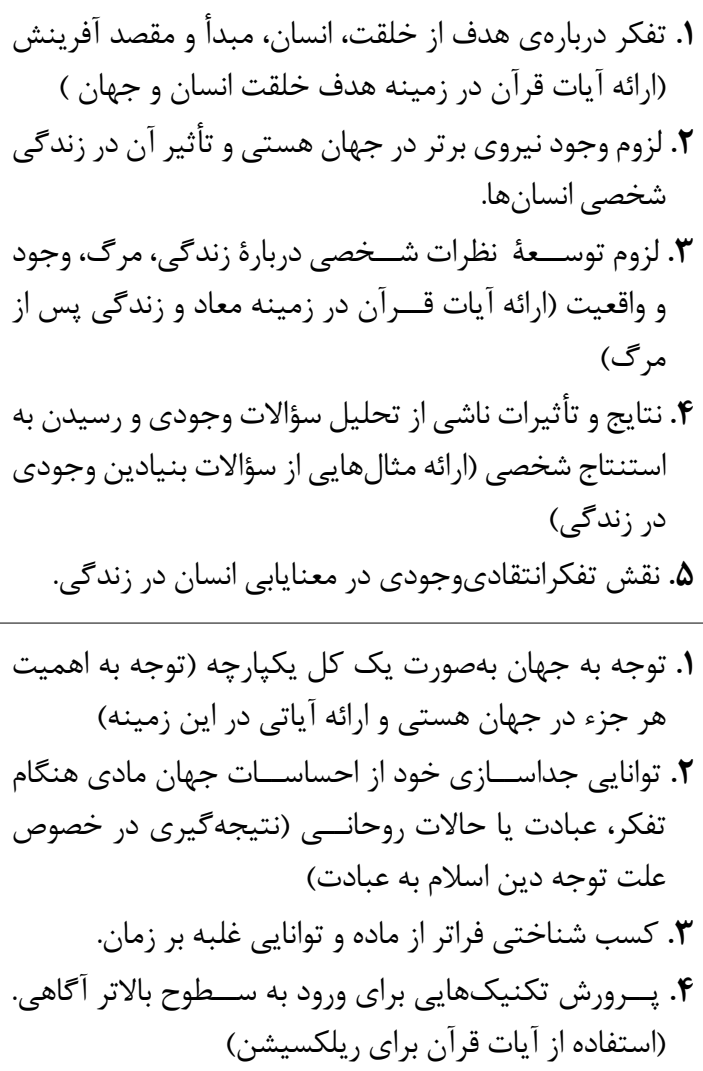 & آموزش تفكر انتقادى & هشتم \\
\hline ֶاسخ به سوالات، انجام پس آزمون (مسئوليتيذيرى). & جمعبندى مطالب حذشته & دهم \\
\hline
\end{tabular}

\section{ابزارهاى تردآورى اطلاعات}

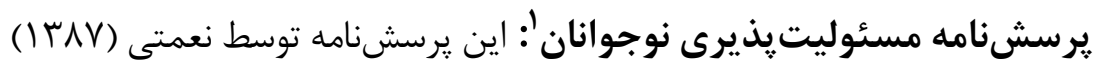
با نظارت كرمىبهمنظور سنجش مســـوليتيذيرى نوجوانان ساخته و مورد هنجاريابى قرار گرفته است. اين يرسشنامه شامل •ه سؤال مىباشد كه V بعد را به شرح زير مورد سنجش و بررسى قرار مى دهد: 
رابطه بين متغيرهاي هوش معنوى والدين و معلمانو

جدول r. سؤالهاى مربوط به عوامل مسئوليتيذيرى در ير سشنامه نهايى •ه سؤالى

\begin{tabular}{|c|c|c|}
\hline شماره سؤالها & عاملها & 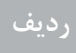 \\
\hline$r \wedge-r r-1 Y-1 r-q-V-\Delta-r-r-r$ & خودمديريتى & 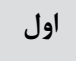 \\
\hline 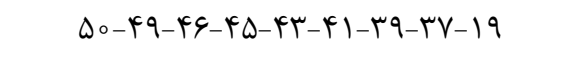 & 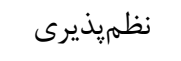 & 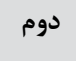 \\
\hline 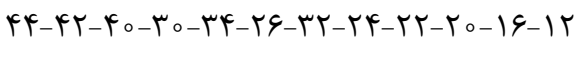 & 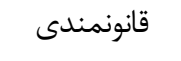 & 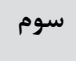 \\
\hline$r 1-r \Delta-r r-\mid \Lambda-11$ & 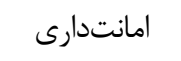 & 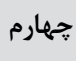 \\
\hline$r Q-r V-r|-| V$ & وظيفهشناسى & 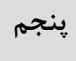 \\
\hline$r \Lambda-r \varepsilon-r \Lambda-10-\Lambda-G$ & سازمان يافتنى & ششم \\
\hline$q V-r \Delta-\mid \Delta-1$ & ريشرفت كرايى & 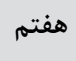 \\
\hline
\end{tabular}

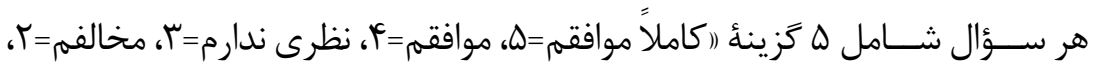

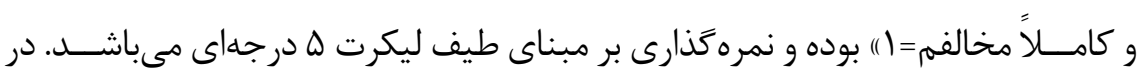

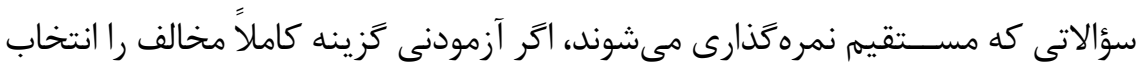

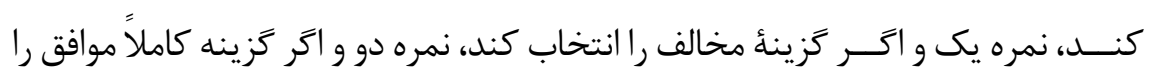

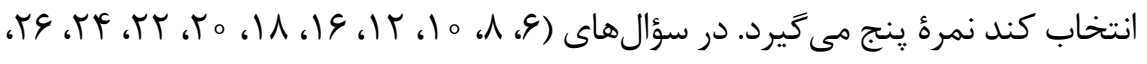

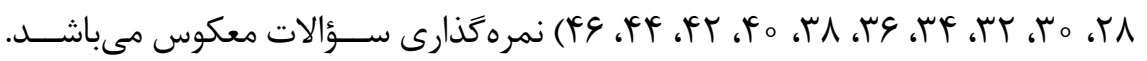

$$
\text { همجنين اين يرسشنامه نمره كل نيز دارد. }
$$

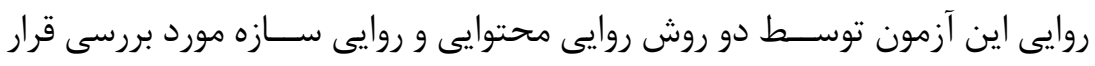

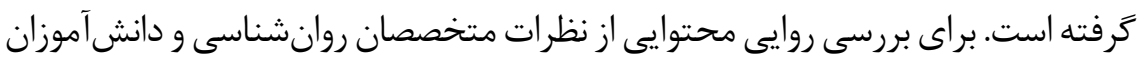

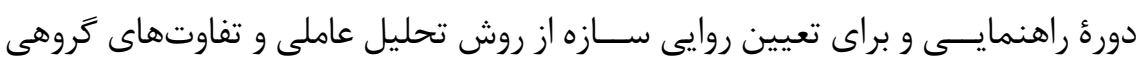

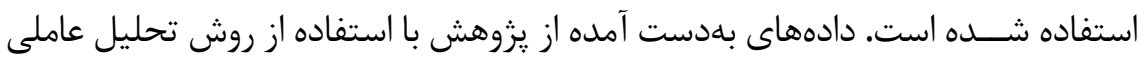

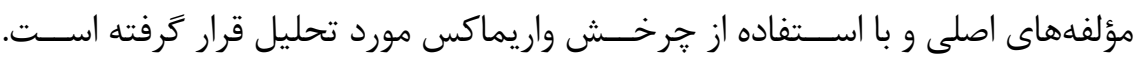

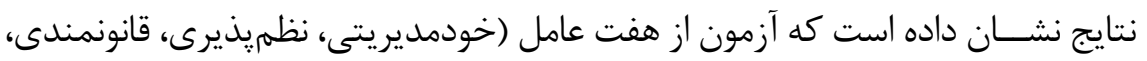

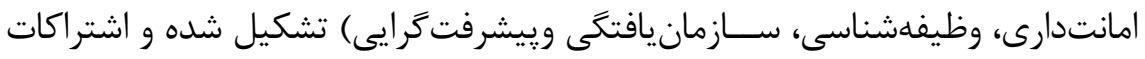

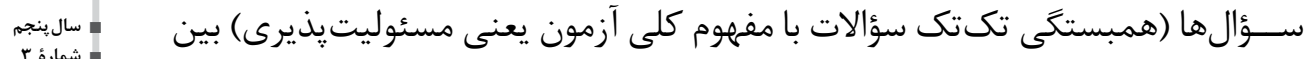

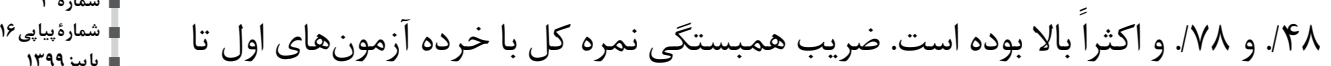




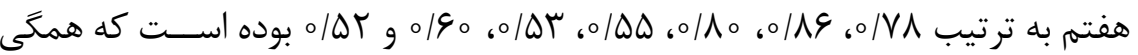
در ســطح //ه معنادار بودند. بررسى روايى سازه از طريق تفاوتهاى گروهى نيز بر روى

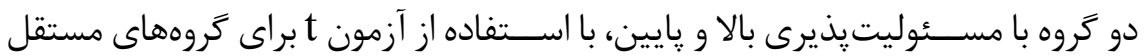
صورت گرفته اســت كه نتايج تفاوت معنادارى را در تمامىهفت عامل ذكر شده، نشان دادهاند. يعنى آزمون مســـئوليتيذيرى محقق ساخته به خوبى توانسته اين دو گروه رازئ يكديكر تفكيك كرده و از روايى ســازه بالايى برخوردار بوده است. در محاسبه يايائى از روش همسانى درونى ضريب آلفاى كرونباخ براى كل يرسشنامه قبل از جرخش،

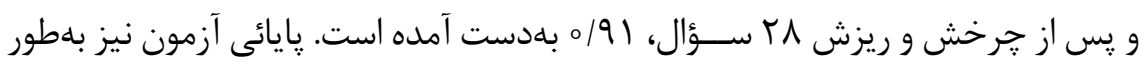
مجدد مورد بررسى قرار زرفته است. ״ايايى اين برســشنامه به روش بازآزمايى براى خرده آزمون اول تا هفتم به ترتيب

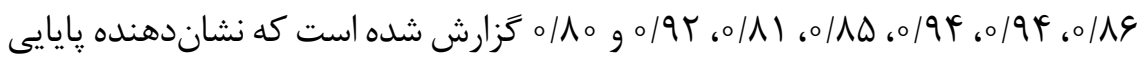
مطلوب و مناسب آزمون است (نعمتى، I INV). سياه منصور (Y (I I ) در تحقيقى ميزان

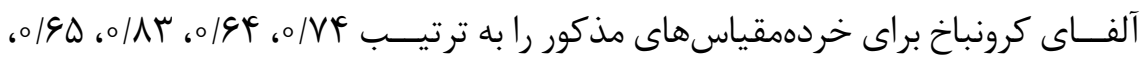

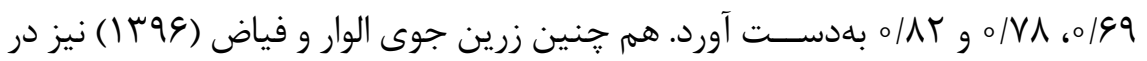

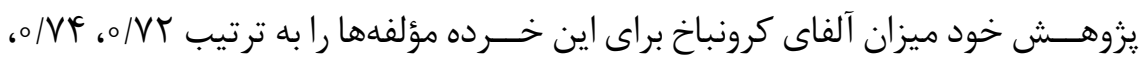

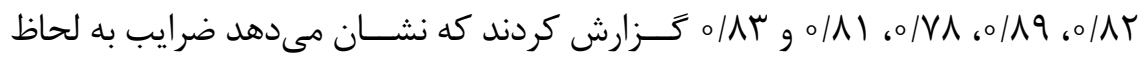
آمارى معنادار مىباشد و اين زيرسشنامه از يايايى برخوردار است.

\section{بافنها}

در اين قســمت بهمنظور تجزيه و تحليل دادهها ابتدا نرمال بـــودن توزيع دادهها با استفاده از آزمون كالموگروف- اســميرنوف انجام شد. سيس نتايج آمار توصيفى شامل ميانگين و انحراف معيار متغيرها بيان گرديد. در ادامه ييش فرضهاى تحليل كواريانس شــامل ييش فرض همخنى شيبهاى رگرسيون و تساوى واريانسها؛ مورد بررسى واقع شـــد و با توجه به نتايج آن در مورد انتخاب آزمون آمارى مناســب (تحليل كوواريانس) تصميمى كيرى شــد. در نهايت جدول تحليل كوواريانس ارايه و به بررسى نتايج يرداخته شده است. تجزيه و تحليل دادهها با استفاده از نرم افزار SPSS و Excel انجام شد. جهت بررسـى نرمال بودن توزيع متغير مســـئوليت يذيرى و مؤلفههاى آن در گروه 
رابطه بين متغيرهاي هوش معنوى والدين و معلمان و

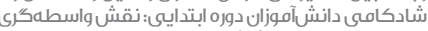

بهزيستى شعنوى دانش

V-rr

آزمايش و گَواه، به تفكيك ييشآزمون و يسآزمون، از آزمون كالموكروف-اسـميرنوف استفاده شد كه در جدول زير آمده است:

جدول F. نتايج آزمون نرماليتى مسئوليت پِيذيرى و مؤلفه هاى آن

\begin{tabular}{|c|c|c|c|c|c|c|c|}
\hline \multicolumn{3}{|c|}{ آزمايش } & \multicolumn{3}{|c|}{ كنترل } & \multirow{2}{*}{ مر احل } & \multirow{2}{*}{ متغيرها } \\
\hline معنادارى & |درجه آزادى | & آماره & معنادارى & |درجه آزادى & آماره & & \\
\hline $0 / / \circ \circ$ & r。 & .1119 & $0109 \mathrm{~V}$ & r。 & - /lQG & بيش آزمون & \multirow{2}{*}{ مسئوليتيذيرى } \\
\hline.$/ 199$ & ro & o/Ira & $\circ / T \circ 0$ & ro & $0 / 0 \wedge 9$ & يسآزمون & \\
\hline$\circ / T_{0}$ & ro & o/ITA & $\circ / r_{0} \circ$ & r。 & سTו & \multirow{2}{*}{ پِيش پِآزمون } & \multirow{2}{*}{ خودمديريتى } \\
\hline $0 / Y \circ 0$ & $\mu_{0}$ & Tr/IT &.$/ / \Lambda \Lambda$ & $\mu_{0}$ & سזוס & & \\
\hline $0 / \| F A$ & r。 & $0 / / \mu \wedge$ & $\circ 1009$ & $r_{0}$ & $0 / 1 \Delta S$ & \multirow{2}{*}{ پِيشآزمون } & \multirow{2}{*}{ نظمهيذيرى } \\
\hline \%०V & ro & -/IQT & $0 / 14 q$ & r。 & o/IrA & & \\
\hline O/IMF & ro & 0||$f \mid$ & $\circ / 1 Q V$ & ro & o/Irv & \multirow{2}{*}{ يِ پِيشآزمون } & \multirow{2}{*}{ قانونمندى } \\
\hline$\circ / T_{0} \circ$ & ro & O/ITA & $\circ / \circ \Delta \Delta$ & ro & $\circ / / \Delta \Lambda$ & & \\
\hline$\circ / T_{0}$ & ro & O/ITI & $\circ / r_{0}$ & ro & $0 / 119$ & \multirow{2}{*}{ ״ֵيش آزمون } & \multirow{2}{*}{ امانتدارى } \\
\hline$\circ / r_{0} \circ$ & ro & o/ITV & $\circ / r_{0} \circ$ & r。 & אוr/ & & \\
\hline$\circ / r_{0} \circ$ & ro & - & $\circ / r_{\circ} \circ$ & ro & $0 / 109$ & \multirow{2}{*}{ ״ِيشآزمون } & \multirow{2}{*}{ وظيفهشناسى } \\
\hline$\circ / Y_{0} \circ$ & ro &.$/ 111$ & $0 / Y \circ 0$ & r。 & $0 / 099$ & & \\
\hline$\circ / T \circ 0$ & r。 &.$/ 110$ & $0 / T \circ 0$ & r。 & $0 / 09 \mathrm{~V}$ & \multirow{2}{*}{ پِيش } & \multirow{2}{*}{ سازمان يافتتى } \\
\hline $.10 V T$ & ro & -/lar & $0 / T_{0} \circ$ & ro & $0 / 094$ & & \\
\hline$\circ / Y \circ \circ$ & r。 & ०/ r & $\circ / r_{0}$ & ro & $\circ / 1 \circ \Delta$ & \multirow{2}{*}{ ״ِيش آزمون } & \multirow{2}{*}{ ييشرفت } \\
\hline $0 / T_{0}$ & ro & $\circ / 1 \circ \mathrm{V}$ & $\circ / T_{0}$ & $r_{0}$ & $0 / 109$ & & \\
\hline
\end{tabular}

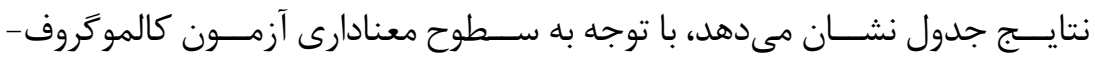

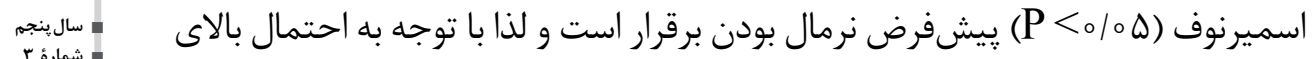

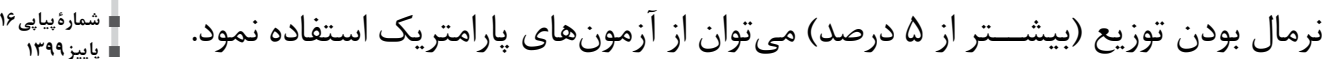


در ادامه براى ارائه نتايج روشــنـتر از يافتههاى يثروهش، ابتدا به بررسى شاخصهاى آمار توصيفى يرداخته شد كه نتايج آن در جدول زير آمده است:

جدول ه. ميانكين و انحراف استاندارد مسئوليت يذيرى و مؤلفههاى آن بر اساس كروه آزمايش و كنترل

\begin{tabular}{|c|c|c|c|c|c|}
\hline \multicolumn{2}{|c|}{ كروه آزمايش } & \multicolumn{2}{|c|}{ تروه كنترل } & \multirow{2}{*}{ منبع } & \multirow{2}{*}{ متغيرها } \\
\hline انحراف معيار & ميانگين & انحراف معيار & ميانگين & & \\
\hline rN/DQ૬ & سM/N1 & $r \Delta / r V_{0}$ & $191 / 10$ & يیشآزمون & \\
\hline$r G / \circ \wedge T$ & TIN/AV & rr/gY。 & $\mid \Lambda F / T V$ & يسآزمون & \\
\hline G/TG人 & MN/Tr & $\Delta / / \backslash V$ & rq/ץ & زمون & \\
\hline$\Delta / 9 \varphi 9$ & Fr/G。 & $N / \circ \Delta F$ & $r V / r V$ & يسآزمون & \\
\hline$V / r \circ 9$ & MF/gr & $g / V 01$ & rr/ro & ز زمون & \\
\hline s/rqd & ५q/IV & N/TAS & سז/r & زمون & \\
\hline N/VG & Fr/Tr & $9 /$ १९६ & $F \Delta / \circ V$ & زمون & \\
\hline$\Lambda / F \vee q$ & $49 / 9 V$ & 1०/VVq & FT/FT & يسآزمون & \\
\hline r/|DI & TY/TV & r/ר & $T Y / F V$ & زمون & \\
\hline$r / \Delta \Delta \varphi$ & rE/OT & r/Irq & Tr/DT & يسآزمون & \\
\hline אץF & 19100 & T/KGq & $19 / \mathrm{VV}$ & ييش آزمون & \\
\hline t/TAT & $19 / 98$ & r/AGT & $19 / 0 \circ$ & يسآزمون & \\
\hline$f / \circ \varphi q$ & $19 / 10$ & $1 / 911$ & IN/DH & ييشآزمون & \\
\hline T/TYG & מ & Q/०^ৎ & $1 N / V_{0}$ & يسآزمون & \\
\hline$r / 9 \circ \circ$ & ID/VT & $r / T / 9$ & $\mid \Delta / \Lambda \circ$ & ييش آزمون & \\
\hline r/VVq & ro/0o & $r / 9 V V$ & $\mid \omega / \circ r$ & يسآزمون & \\
\hline
\end{tabular}




\begin{tabular}{|c|c|c|c|c|c|}
\hline \multicolumn{6}{|c|}{ 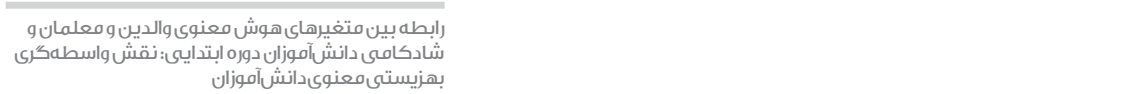 } \\
\hline \multicolumn{6}{|c|}{ 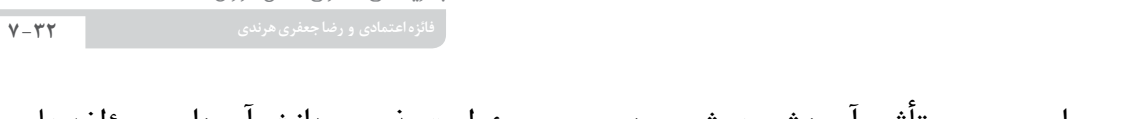 } \\
\hline \multicolumn{6}{|c|}{ در زير آمده از تحليل كوواريانس استى تأثير آموزش هوش معنوى بر مسئوليتيذيرى دانش آموزان و مؤلفههاى شد. اما قبل از آن به مفروضههاى آن پرداخته شد كه } \\
\hline \multicolumn{6}{|c|}{ جدول צ. نتيجه آزمون لون براى بررسى يِيشفرض تساوى واريانسها } \\
\hline سطح معنادارى & $d^{r}{ }^{r}$ & df ${ }^{\prime}$ & f & 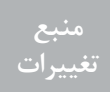 & متغير / \\
\hline - & $\Delta \Lambda$ & 1 & $r / 09 V$ & & مسئوليتيذيرى \\
\hline 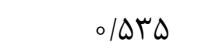 & $\Delta \Lambda$ & 1 & ०/ґ^৭ & & خودمديريتى \\
\hline$\circ / 0 \wedge \circ$ & $\Delta \Lambda$ & 1 & $r / I V I$ & & نظميذيرى \\
\hline O/ITE & $\Delta \Lambda$ & 1 & $t / 4, G$ & & قانونمندى \\
\hline $0 / 10 r$ & $\Delta \Lambda$ & 1 & T/VAV & & امانتدارى \\
\hline $0 / 4 \& 4$ & $\Delta \Lambda$ & 1 & OLAT & & وظيفهشناسى \\
\hline$\circ / 0 \Delta \varphi$ & $\Delta \Lambda$ & 1 & $\Delta / \Delta \Delta \Lambda$ & & سازمانيافتكىى \\
\hline$\circ / \mathbb{F} \wedge 。$ & $\Delta \Lambda$ & 1 & $\circ / 0 \circ 9$ & & يِيشرفت \\
\hline
\end{tabular}

آزمون لون پيشفرض تسـاوى واريانسهاى دو كروه آزمايش و كنترل را در جامعه

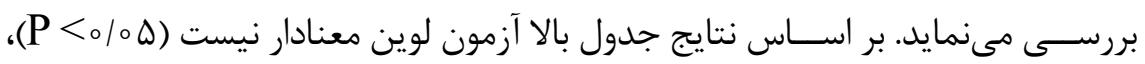

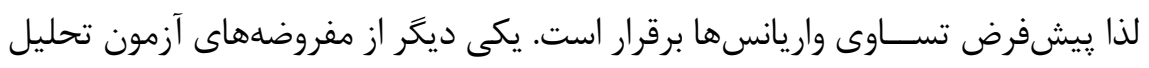

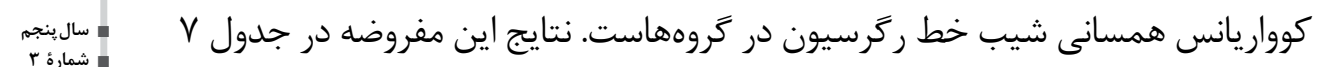


جدول V. خلاصه نتايج بررسى همكنى شيبهاى رَرسيون از اثرات درون آزمودنىها مسئوليت يذيرى و مؤلفه هاى آن رئن

\begin{tabular}{|c|c|c|c|c|c|}
\hline معنادارى سطح & $\mathrm{F}$ & مجيانگين مجموع مجورات & آزادى درجه & مجنموروات & شاخص آمارى \\
\hline$\circ / \mathbb{F} \circ \circ$ & $\circ / \mathrm{V} \backslash$ & GKN/GF。 & 1 & GrN/GY。 & زَمون مسئوليت هذيرى * خروه \\
\hline.$/ I r V$ & r/rqq & Irt/GDA & 1 & $\mid r m / 9 \Delta \lambda$ & مون خودمديريتى * كروه \\
\hline$\circ / 9 \vee 9$ & $\circ / 0 \circ 1$ & $\circ / 0 \mathrm{fF}$ & 1 & $0 / 0$ fF & لمون نظمهيذيرى" كروه \\
\hline$\circ / \Delta \circ \Delta$ & $\circ / F \Delta \mid$ & $F \circ / T F V$ & 1 & $F \circ /$ KFV & مون قانونمندى" كَروه \\
\hline o/VFV & $\circ / 1 \circ \Delta$ & $\circ / 94 \wedge$ & 1 & olgFᄉ & زَمون امانتدارى" "حروه \\
\hline ॰/9\%。 & 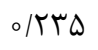 & I/ATA & 1 & I/ATA & زآمون وظيفهشناسى " كروه \\
\hline $0 / 194$ & l/Vrq & rq/ TrF & 1 & rq/ TrF & ييش آزمون سازمانيافتخى * كروه \\
\hline$O / F T I$ & $\circ|99|$ & G/0 TF & 1 & G/OTF & ييشآزمون ييشرفت \\
\hline
\end{tabular}

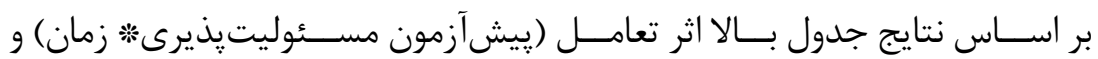

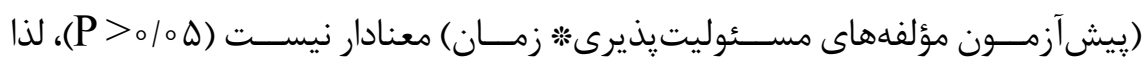
شيبهاى رگرسيون همخنى دارند و از اين مفروضه تخطى نشده است. جدول ^. نتايج آزمون جندمتغيرى مسئوليت يذيرى و مؤلفههاى آن

\begin{tabular}{|c|c|c|c|c|c|c|}
\hline مجذور اتا & معنادارى سطع & آزادى بـ & آزادى ا & F & مقدار آماره & آزمون \\
\hline ./91T & $<\circ / 0 \circ \circ \Delta$ & Fa & V & $\mid r / V G \Lambda$ & ./91T & اثرييلايى \\
\hline$\circ / 9 \wedge T$ & $<\circ / \circ \circ \circ \Delta$ & id & V & IT/VGA & 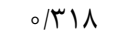 & لامبداى ويلكز \\
\hline o/GAr & $<\circ / 0 \circ \circ \Delta$ & Fa & V & Ir/VGA & t/IFt & اثرهاتلينَ \\
\hline o/G人T & $<\circ / \circ \circ \circ \Delta$ & id & V & IT/VGA & T/IFT & بزرَترين ريشهروى \\
\hline
\end{tabular}




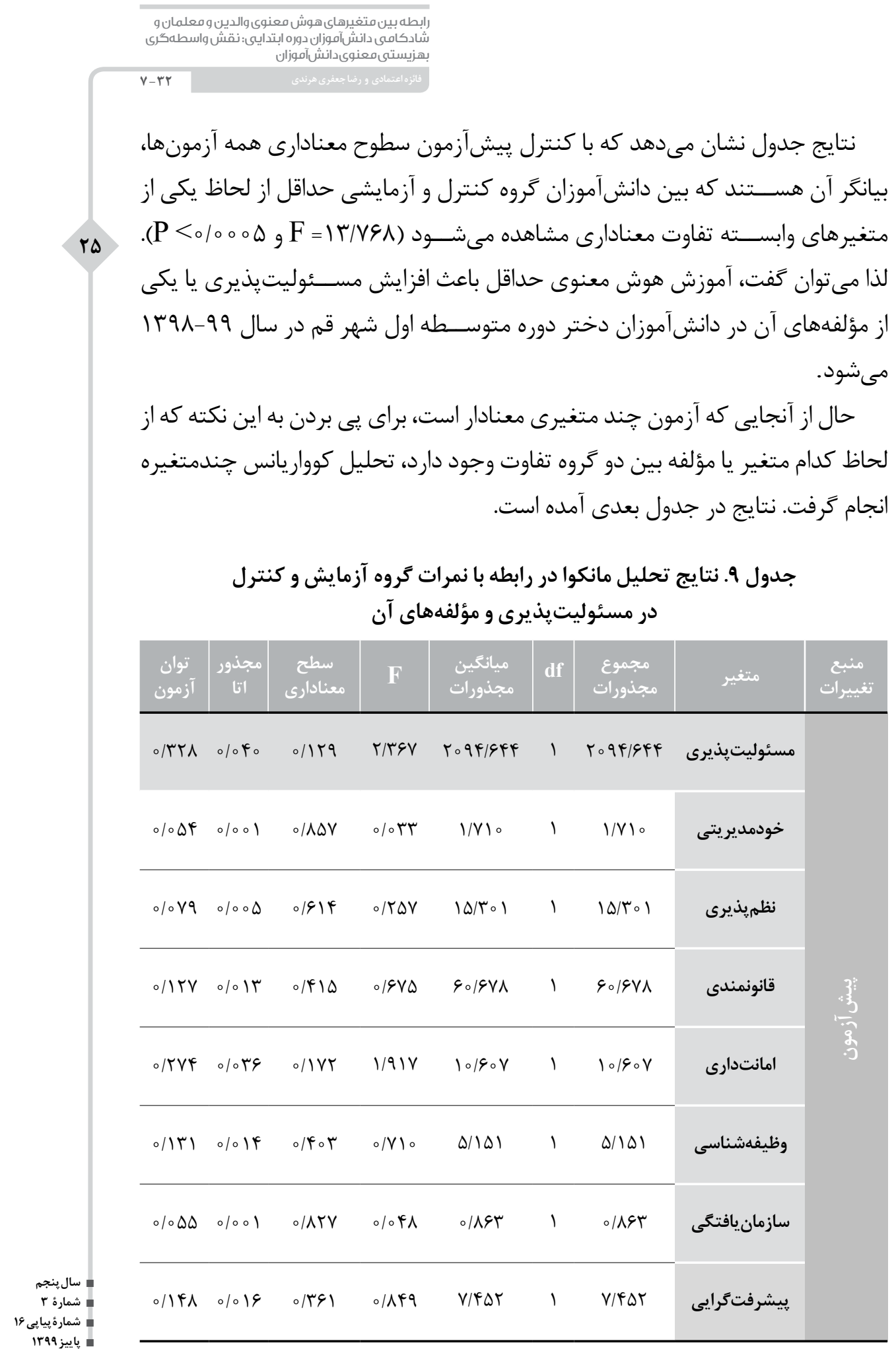




\begin{tabular}{|c|c|c|c|c|c|c|c|c|}
\hline آزمون & اتا مجنور & معنادارى سطح & F & مجنفورات & df & مجنجورات & متغير & نفييرات \\
\hline.$/ 990$ & $0 / 499$ & $<\circ / 0 \circ \circ \Delta$ & ro/990 & INDAY/FHY & 1 & $\mid \Lambda \Delta \Lambda T / F H F$ & مسئوليتيذيرى & \\
\hline olAVT & ollgt & س० & १/१७ & DIN/IKA & 1 & هINIIN & خودمديريتى & \\
\hline o/9ra &.$/ 191$ & $0 / 001$ & س & VFG/VYT & 1 & VFG/VTY & نظمهيذيرى & \\
\hline$\circ / \pi \wedge \Delta$ & $\circ / \circ \Delta F$ & .1099 & r/ANK & $r \Delta q / \circ \wedge V$ & 1 & $r \Delta 9 / \circ \wedge V$ & قانونمندى & \\
\hline $1 / 000$ & o/fVG & $<\circ / \circ \circ \circ \Delta$ & 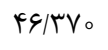 & 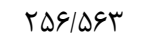 & 1 & 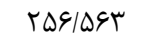 & امانتدارى & \\
\hline.$/ 991$ & O/TH & $<\circ / 0 \circ \circ \Delta$ & rF/VqA & IVa/AIT & 1 & IVq/AIT & وظيفهشناسى & \\
\hline$\circ / 990$ & o/TVF & $<0 / 00 \circ \Delta$ & 19/rar & rFs/IV。 & 1 & rFs/IV。 & سازمانيافتتى & \\
\hline $1 / 000$ & o/fra & $<\circ / 0 \circ \circ \Delta$ & 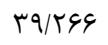 & MFY/gFi & 1 & MFYGYSI & بيشرفت & \\
\hline
\end{tabular}

نتايج جدول نشــان مى دهد، با در نظر گرفتن نمرات ييش آزمون بهعنوان متغيرهاى كمكىى: تفاوت بين عملكرد دانش آموزان دختر دوره متوســطه اول شــهر قمم در ســال

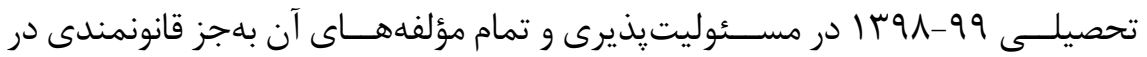
دو ₹ــروه آزمايش و كنترل معنادار اسـت ( (P > P) در متغير قانونمندى تفاوت در

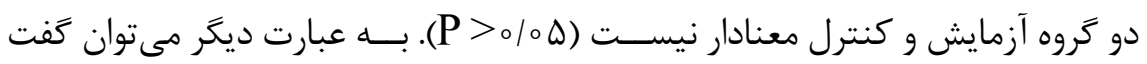
تفاوت بين نمرات دو گروه از دانشآموزان دختر دوره متوســـه اول شـــر قم در سال

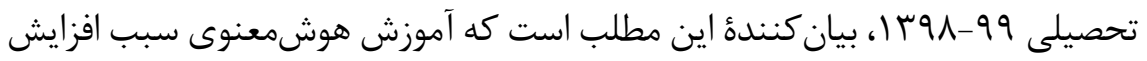
مسئوليت يذيرى تمام مؤلفههاى آن بهجز قانونمندى مىشود اما در مؤلفهى قانونمندى

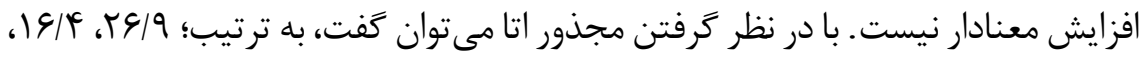

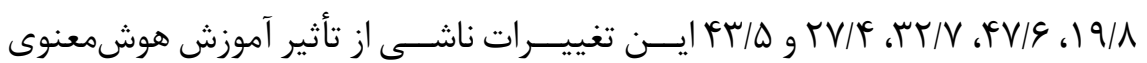
در مسئوليت يذيرى، خودمديريتى، نظميذيرى، قانونمندى، امانتدارى، وظيفهشناسى، سازمانيافتخَى و ييشرفت گر ايى بوده است. 


\section{بحث و نتيجه كَيرى}

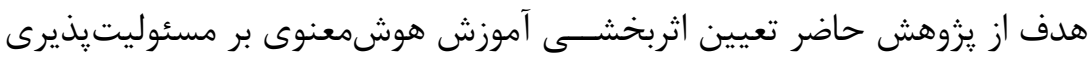

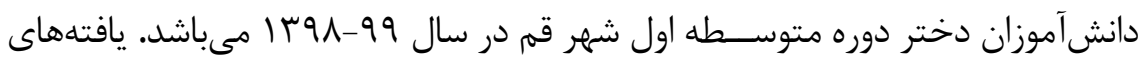

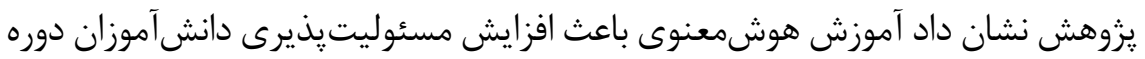

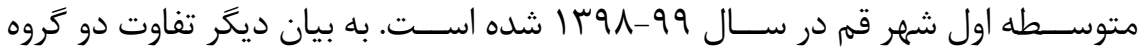

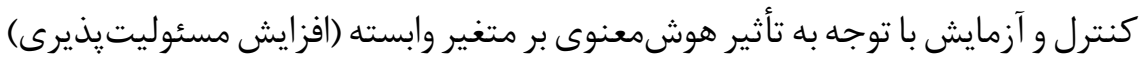

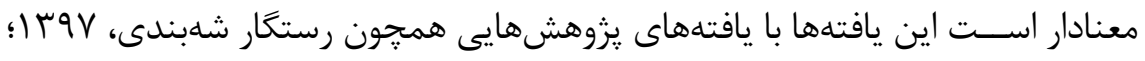

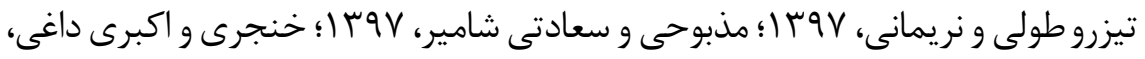

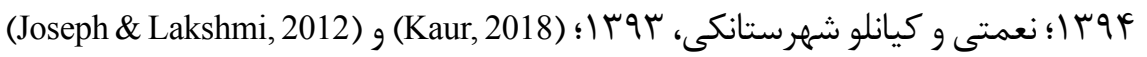
همسو مىباشد. در تبيين اين يافتهها مىتوان كفت آموزش هوش معنوى مى تواند درك مبدأ و مقصد

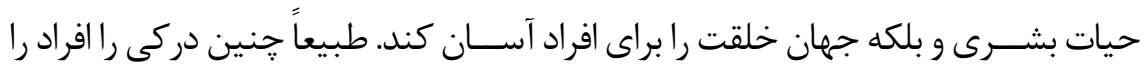

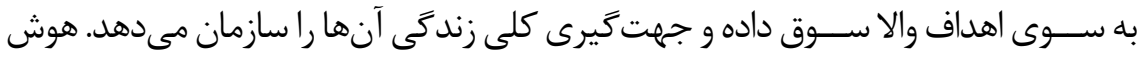

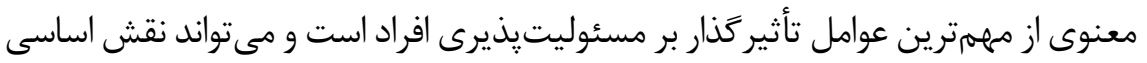

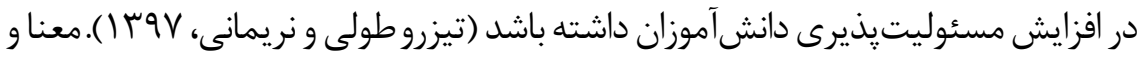

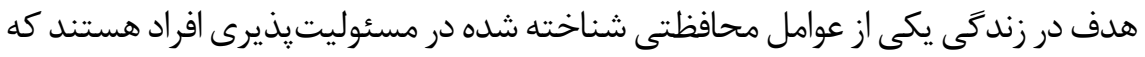

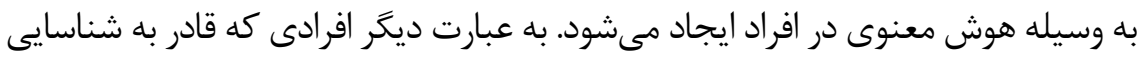

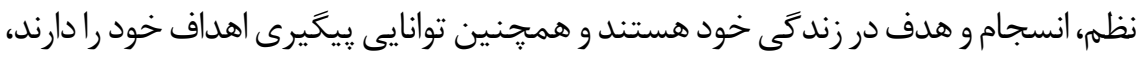

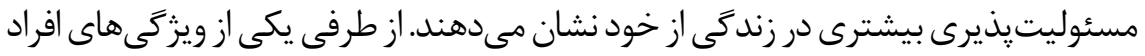

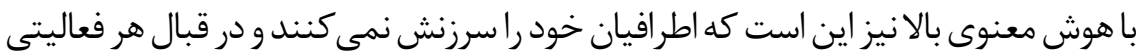
احساس مسئوليت مى كنند و وابسته به موقعيت ديكران نيستند، لذا مسئوليت يذئيرى بالايى

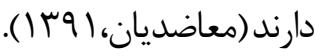
علاوه بر آن برخى تحقيقات انجام شـــده نشان مى دهند كه خوشبينى، يافتن معنا در

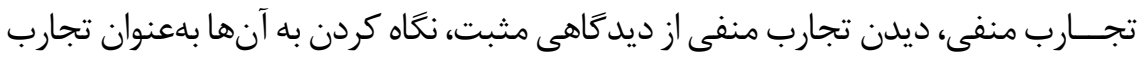

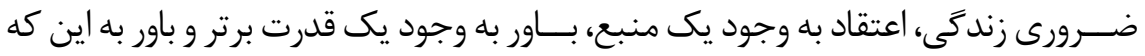

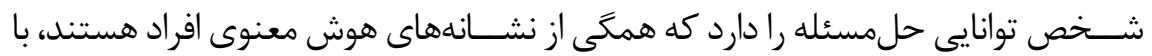

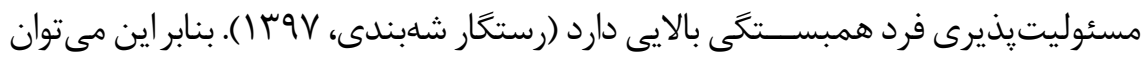


كَفت رشد هوش معنوى منجر به شكل گيرى هدف، معنا، خودآكاهى، بينش عميق، استقلال

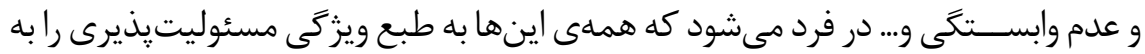
دنبال خواهند داشت.

از طرفى ويزگَى مسئوليتيذيرى افراد تحتتأثير عوامل اجتماعى و فرهنگَى متنوعى قرار دارد. جُند عامل اساســى در مسئوليتيذيرى انسانها نقش دارد كه يكى از اين عوامل ديندارى يا معنويّت اســت. خداوند متعال نيز در قرآن كريمى انسان را فردى مسئوليتيذير معرفى مى كند آيا انســان مى يندارد كه آزاد و رهاو بـى مسئوليت است؟ يكى از مرمترين مؤلفههاى سبك زندگَى اسلامى موضوع مسئوليتيذيرى در زندگى است. در واقع اين مؤلفه است كه به زندكى انسان رنت و بوى الهى و دينى مى دهد. جرا كه انسانى كه خود را تابع و ييرو هيج قانون و مذهبى قرار نمى دهد و زيربار هيج مســـوليتى نمىرود، نمى تواند روح زندگى دينى را درك نمايد. ازين رو در ســبك زندگى اسلامى و معنوى مسئوليتهاى

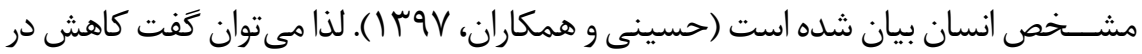
اعتقادات و ديندارى افراد، زمينهُ بىمسئوليتى و ناهنجارىهاى اجتماعى رافراهم مىسازد، يس با توجه به معنويت و ديندارى مىتوان از بى هنجارىها در جامعه كاست. بهعبارتديكر داشـــن التزام به هنجارهاى دينى و انجام مناسك مذهبى، در بالا بردن مسئوليتيذيرى اجتماعى كنشخران تأثير اساسى دارد.

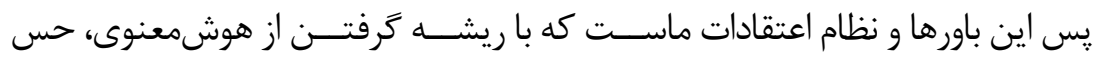
مسئوليتيذيرى را در ما تقويت نموده و به گَونهاى به شخصيت ما شكل مى دهد كه تعرّد و قبول مسئوليت هر آنجه راكه يذيرفتهايمم رادر تمام عرصهها به عهده بخيريهم وبه مطلوبترين نحو ممكن انجام دهيه. مسئوليت يذيرى تنها قبول انجام امور نيست بلكه انجام درست كارها رانيز شامل مىشود. همجنين يافتههاى ديگر يزوهش نشان داد كه تفاوت بين عملكرد دانش آموزان دختر در تمام مؤلفههاى مسئوليت پذيرى بهجز قانونمندى در دو كروها آزمايش و كنترل معنادار است.به عبارت ديخر مى توان گفت آموزش هوشمعنوى سبب افزايش تمام مؤلفههاى مسئوليت بهجز قانونمندى مىشـــود اما در مؤلفهى قانونمندى افزايش معنادار نيست.اين يافتهها با

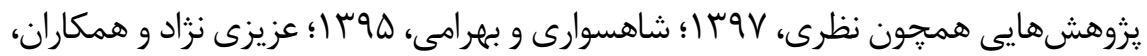

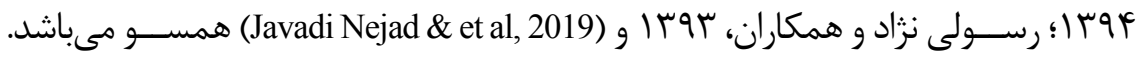


V-rt

در تبييــن اين يافتهها مى توان كفت هوش معنوى منجر به يرورش احســاس رضايت درونى، انضباط درونى، ايجاد انخيزش درونى قوى، رشد تفكر و افزايش قدرت شناختى، كسب اعتماد به نفس، ايجاد روحيه شادابى و نشاط، صرفهجويى در هزينههاى زندگى و مورد توجه

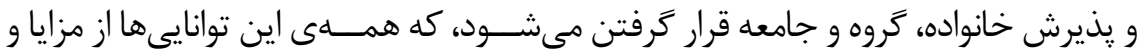

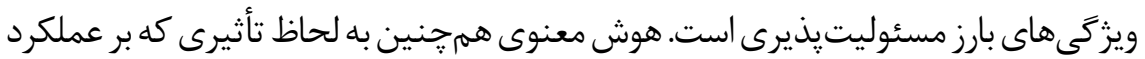
فرد بهعنوان زيربناى باورهاى فرد مى گذارد، موجب افزايش تعهد و مسئوليت يذيرى بيشتر افراد شده و به بهبود كار آيى فردى و گروهى مىانجامد و سرانجام مىتواند رفتار فرد رابه سوى موفقيت و سعادت دنيوى و اخروى هدايت كند و بادر نظر گرفتن اين نكته كه هوش معنوى قابل آموزش و تقويت هست، مىتوان با رشد و تقويت اين عامل موفقيت در بين دانش آموزان، به توانمندسازى آنان در تمامىابعاد تحصيلى، شغلى و اجتماعى و حتى معنوى كمك نمود (تيزروطولى و نريمانى، Vq I ). از طرفى از آنجا كه انسان موجودى اجتماعى است و در يكى له مجموعهى اجتماعى زندگَى مى كند، نســبت به آن احساس تعلق دارد و اين احساس تعلق به خانواده، فاميل، فرهنًَ، گروههاى همسال و از همه مهلمتر مذهب و باورهاى معنوى نيز، احســاس ارزشــمند بودن رادر كودكان ايجاد كند، عزّتنفس را در آنها رشد دهد و باعث تقويت حسّ مسئوليت يذيرى و خودآكاهى در آنان مىشود (نعمتى، I IVV) باورهاى معنوى همجنين مى توانند احساس آرامش و تمركز را در دانشآموزان به همراه داشته باشند و اين احساس با افزايش يادگيرى و تقويت اعتماد به نفس و احساس مسئوليتيذيرى همراه است.

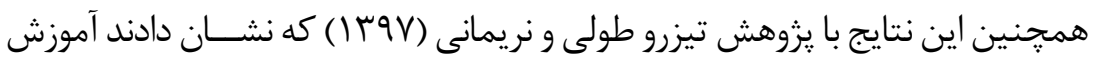
هوش معنوى بر قانونمندى دانشآموزان تأثير مثبت دارد، ناهمسو مى باشد. اما بلنظر مىرسد اين ناهمسويى صرفاً به دليل نمونهى يزوهش و ابزار يزوهش ها باشد. اين احتمال نيز وجود دارد كه دانشآموزان در ير كردن يرسشنامهها دقت لازم را به عمل نياورده باشند.

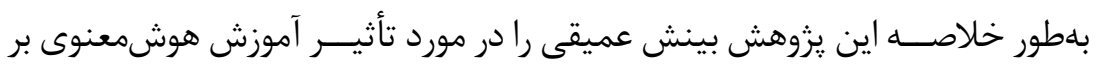

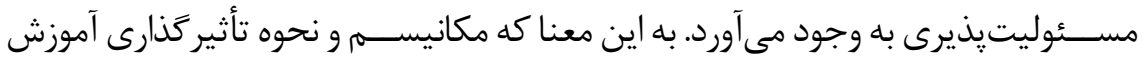
هوشمعنوى بر مســـئوليتيذيرى را تفهيهم مى كند كه مىتواند براى مشـــاوران مدارس، روانشناسان تربيتى، معلمان و بهطور كلى براى كسانى كه با آموزش و يادكيرى سرو كار دارند كاربرد فراوانى در مواجمه با مشكلات عدم مسئوليت يذيرى دانش آموزان داشته باشد. با توجه به اينكه دانش آموزان مقطع متوسطه به سن بلوغ رسيدهاند و بسيارى از مشكلات دانش آموزان 
در اين مقطع هويدا مىشود يِيشنهاد مىشود آموزش هاى هوش معنوى بهصورت كار گاهى براى مربيان : برورشى، مشاوران و مديران محترم مدارس ارائه شود تا بتوانند با آحاهى كامل در اين زمينه اطلاعاتى را بهطور مســتقيمى و غير در اختيار دانشآموزان بحذارند. همجنين برنامهريزان درسى مى توانند براى رشد هوش معنوى در دانشآموزان در دروسى مانند بينش و دين و زندگى با گنجاندن مطالبى موجب تعمق فرد در مورد ابعاد متعالى و ماورايى خود، ديگران و جهان شوند و همجنين با به تفكر وا داشتن در زمينههايى از قبيل مرگ و زندگى، زندگى يس از مرگ، مسئوليت فرد در قبال ديخران و... منجر به رشد مسئوليت گردند. بهعلاوهوالدين مىبايست تلاش كنند تااز كودكى احساس تعلق به باورهاو ارزش هاى معنوى رااز طريق شركت در مراسمات مذهبى و صحبت دوستانه بانوجوانان رادر آنها ايجاد كرده و اهميت مسئوليتيذيرى در اديان و باورهاى معنوى را به آنها كوشزد كنند تا ازين طريق منجر به رشد مسئوليت يذيرى در آنها شوند. در نهايت نيز ذكر اين نكته ضرورى است كه اين يزوهش همانند ديخر يزوهشها هارهاى محدويتهايى است:اول اينكه در تحقيقات آزمايشى كنترل آزمودنى دشوار است، لذا ييشنههاد مىشود اين يثروهش با روش همبستخى نيز انجام شود. محدوديت جنسى موجود در جامعه آمارى (دختر بودن آزمودنىها) و همجنين انجام يزوهش در مقطع متوسطه اجازهى تعميمم يافتههاى يزوهش را به كل دانشآموزان دختر و گِر و ديگر مقاطع تحصيلى نمى

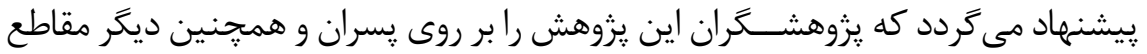
و دانشخاهها اجرا نمايند تا قابليت تعميمم نتايج افزايش يابد. در رابطه با متغيرهاى يزوهش

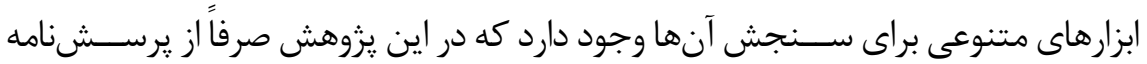
مسئوليت ڤذيرى نوجوانان نعمتى (1 I ) ) استفاده شده است و اين مى تواند باعث محدوديت در تعميهم نتايج شود، لذا ييشنهراد مى گردد در تحقيقات مشابه از ابزارهاى ديخرى كه براى سنجش مسئوليت يذيرى استفاده شود تا تعميم گذيرى نتايج گسترش يابد.

\section{تشكّر و قدردانى \\ از معاونت محترم يثروهشى دانشخاه قم، بهخاطر همكارى در اجراى يزوهش حاضر ، سياسگز ارى مىشود.}




\section{منابع}

قرآن كريم

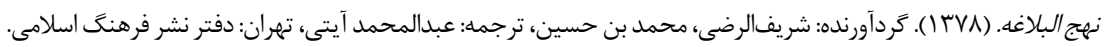
بذرافشـان، محمدرضـا. (

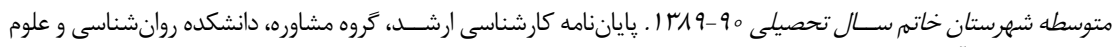

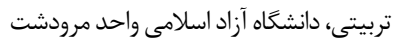

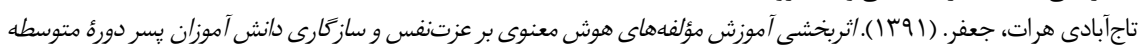

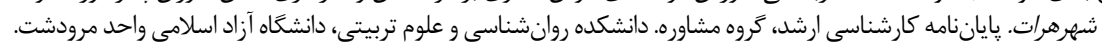

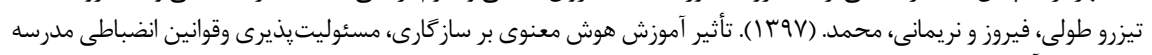

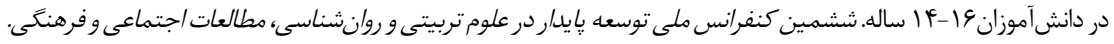

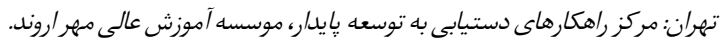

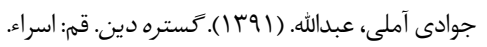

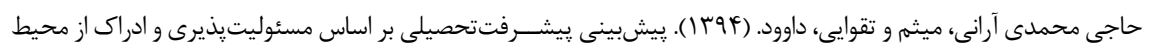

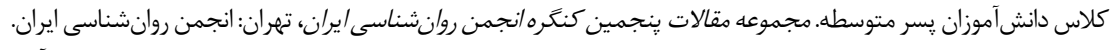

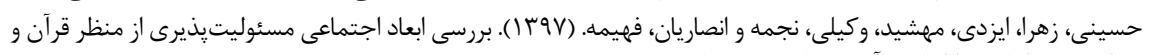

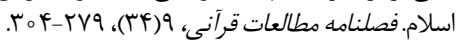

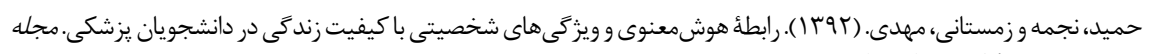

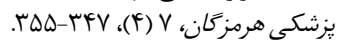

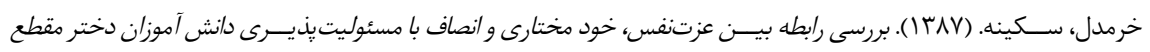

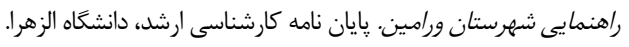

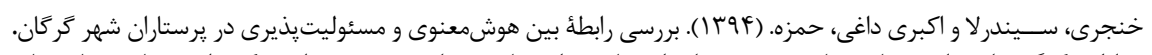

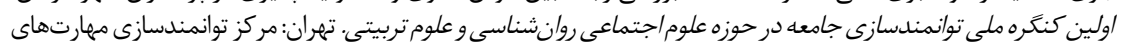
فرهنگ ولى و اجتماعى جامعنه.

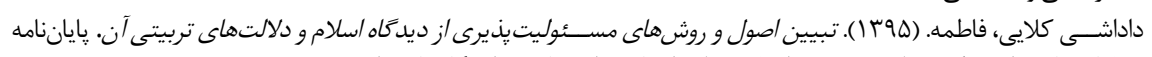

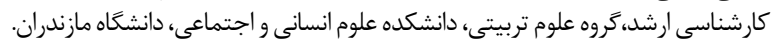

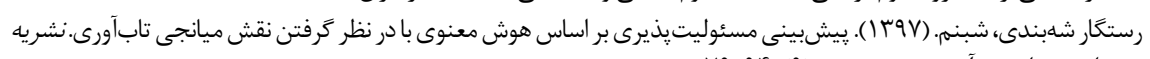

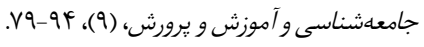

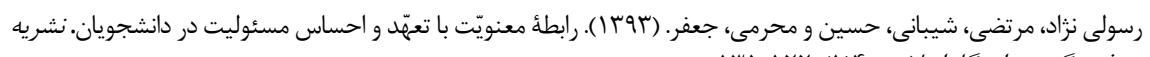

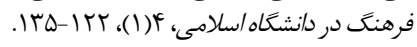

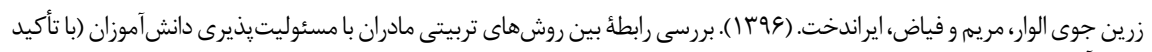

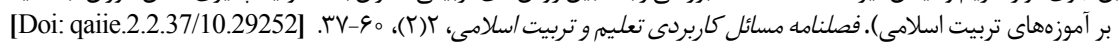

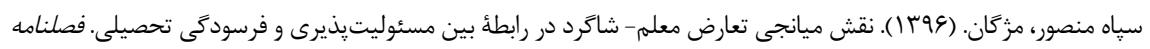

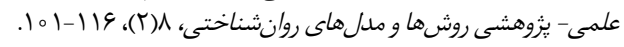

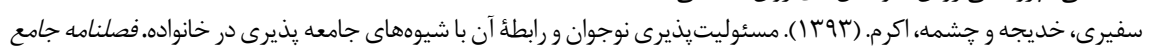

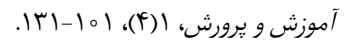

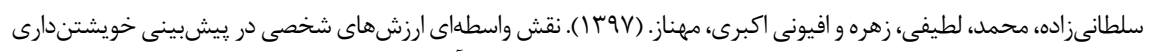

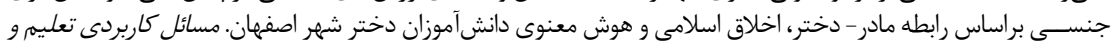
[Doi: qaiie.3.2.87/10.29252]

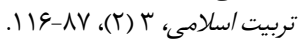
[Doi: 10.22054/RJQK.2017.8719]

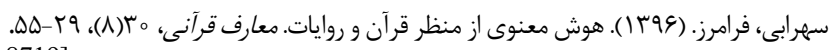

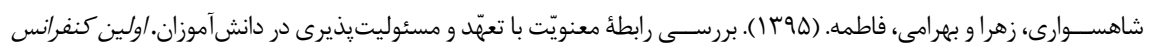

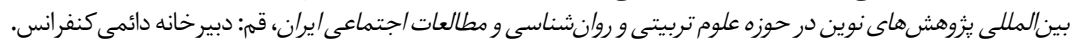

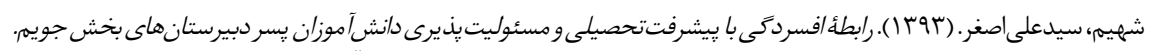

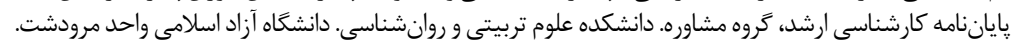

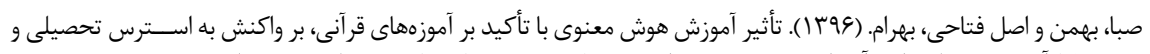

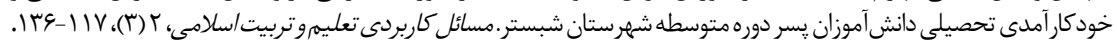
[Doi: qaiie.2.3.117/10.29252] 


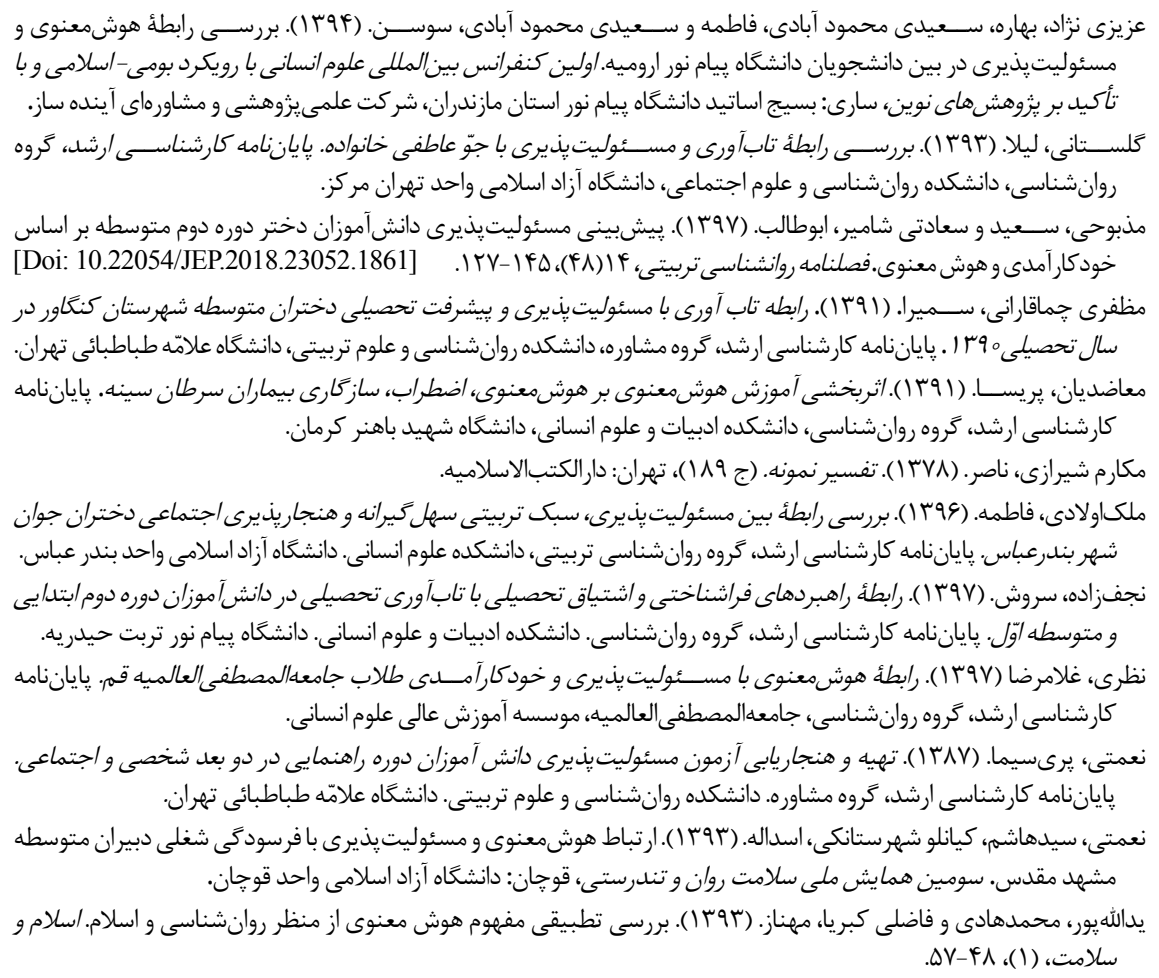

\section{REFERENCES}

Clemes, H., \& Bean, R. (1990). How to teach children responsibility. PSS Adult.

Gupta, G. (2012). Spiritual intelligence and emotional intelligence in relation to self-efficacy and selfregulation among college students. International Journal of Social Sciences \& Interdisciplinary Research, 1(2), 60-69. [Doi: 10.12691/education-4-15-6].

Jain, M., \& Purohit, P. (2006). Spiritual intelligence: A contemporary concern with regard to living status of the senior citizens. Journal of the Indian Academy of Applied psychology, 32(3), 227- 233.

Javadi Nejad, A., Heidari, A., Naderi, F., Bakhtiyar Pour, S., \& Haffezi, F. (2019). Effectiveness of Spiritual Intelligence in Resilience and Responsibility of Students. International Journal of School Health, 6(3). [Doi: 10.5812/intjsh.86677].

Joseph, C. \& Lakshmi, S. S. (2012). Spiritual Intelligence at Work. The IUP Journal of Soft Skills, v (4), 21-30.

Kaur, H. (2018). Life Skills Social-responsibility and Decision-making as Correlates of the Spiritual Intelligence of Student Teachers. International Journal of Education, 9, 15-21.

King, DB.(2008). Rethinking claims of spiritual intelligence: A definition model and measure. Journal of Existential Psychology and Psychotherapy.3(1), 44-87.

Mead, m. (1970). Culture and commitment: A study of the generation gap. Garden city, NY: Natural history press/ Dobleday.

Sisk, D. (2008). Engaging the spiritual intelligence of gifted student to buil global awareass in the classroom. Academic research library. 30(1),24- 30. [Doi:10.1080/02783190701836296].

Zohar, D., Marshall, I. (2000). SQ: Spiritual intelligence, the ultimate intelligence. London: Blooms bury. 